\title{
Etiologic role of root canal infection in apical periodontitis and its relationship with clinical symptomatology
}

\section{Brenda Paula Figueiredo de Almeida GOMES(a) \\ Daniel Rodrigo HERRERA ${ }^{(a)}$}

(a) Universidade Estadual de Campinas Unicamp, Piracicaba Dental School, Department of Restorative Dentistry, Piracicaba, SP, Brazil.
Declaration of Interest: The authors certify that they have no commercial or associative interest that represents a conflict of interest in connection with the manuscript.

\section{Corresponding Author:}

Brenda Paula Figueiredo de Almeida Gomes bpgomes@fop.unicamp.br

https://doi.org/10.1590/1807-3107bor-2018.vol32.0069

Submitted: May 21, 2018

Accepted for publication: May 29, 2018

Last revision: June 12, 2018
Abstract: Evidence shows the polymicrobial etiology of endodontic infections, in which bacteria and their products are the main agents for the development, progression, and dissemination of apical periodontitis. Microbial factors in necrotic root canals (e.g., endotoxin) may spread into apical tissue, evoking and supporting a chronic inflammatory load. Thus, apical periodontitis is the result of the complex interplay between microbial factors and host defense against invasion of periradicular tissues. This review of the literature aims to discuss the complex network between endodontic infectious content and host immune response in apical periodontitis. A better understanding of the relationship of microbial factors with clinical symptomatology is important to establish appropriate therapeutic procedures for a more predictable outcome of endodontic treatment.

Keywords: Periapical Periodontitis; Periapical Diseases;

Lipopolysaccharides; Cytokines; Matrix Metalloproteinases.

\section{Introduction}

Apical periodontitis is mainly a consequence of root canal infection, characterized by inflammation and destruction of periradicular tissues resulting from the interaction between microbial factors and host immune response. ${ }^{1}$ Evidence has reinforced the microbial role in apical periodontitis; ${ }^{2}$ however, given the diversity of the endodontic microbiota and its different virulence factors, the exact pathogenic roles of microbial species have been under investigation to determine whether any particular group of bacteria is associated with specific endodontic symptoms and clinical signs.

Gram-negative bacteria predominate in root canals of teeth with pulp necrosis and periapical lesions. $3,4,5,6,7,8,9,10,11,12$ Among the virulence factors of gram-negative bacteria, lipopolysaccharides (LPS/endotoxins) are especially important in endodontic infection because of their biological effects, which lead to a complex interplay with host factors, resulting in clinical symptomatology, inflammatory reaction, and resorption of mineralized tissues. ${ }^{4,11,12,13,14,15,16,17,18,19,20}$ On the other hand, lipoteichoic acid (LTA), present in gram-positive bacteria, shares its pathogenic properties with lipopolysaccharides (LPS), ${ }^{21,22}$ resulting in well-known injuries to the dental pulp and periapical tissues. In general, both LPS and LTA are 
able to potently activate monocytes/macrophages, causing rapid release of cytokines at periradicular sites related to tissue destruction..$^{21,22}$

Destruction of the periodontal ligament is triggered by degradation of the extracellular matrix by metalloproteinases (MMPs), ${ }^{23}$ involving periradicular inflammation and bone destruction mediated by proinflammatory cytokines. ${ }^{24}$

LPS are the most potent stimuli for immune cells regarding the release of several inflammatory mediators (e.g., IL-1 $\alpha$, IL-1 $\beta$, TNF- $\alpha$, IL-6, $\mathrm{PGE}_{2}$, IL-10, and MMPs) ${ }^{11,12,17,25,26,27,28,29,30}$ and, consequently, they are associated with clinical symptomatology. $11,12,13,15,16,17,18,19,20,31$

This review of the literature aims to discuss the complex network between endodontic infectious content [(bacteria and virulence factors (endotoxins and LTA)] and host immune response in apical periodontitis. A better understanding of the relationship of microbial factors with clinical symptomatology is important to establish appropriate therapeutic procedures for a more predictable outcome of endodontic treatment.

\section{Etiologic role of bacteria in root canals}

The oral cavity has one of the highest rates of microorganisms. Although viruses, fungi, yeasts, and protozoa can be found in this ecosystem, bacteria account for a larger number, ${ }^{10,32}$ about $10,{ }^{10}$ distributed in 700 species or phylotypes. Approximately 40 to $60 \%$ of these bacteria have not yet been cultured. ${ }^{10,32,33}$

The enclosed anatomy of the dental pulp provides an effective primary barrier against its microbial colonization, once the teeth are part of the oral cavity. Actually, as long as the enamel layer is intact, bacteria will not reach the pulp through the crown. Furthermore, root walls are similarly naturally impermeable. Nevertheless, it is clinically apparent that the dental pulp does become infected. ${ }^{34}$

\section{Pathways of infection}

Under appropriate conditions, the normal oral microbiota may give rise to opportunistic pathogens if access to dental pulp tissues occurs. Openings in the physical barriers of dentin (enamel and cementum) by means of caries, cracks, or traumatic injuries create pathways for bacteria into the root canal system. ${ }^{2,32,35}$
Other routes are exposed dentinal tubules; direct pulpal exposure; restorative procedures; lateral canals of teeth with periodontal involvement; and entry into the systemic circulation, known as anachoresis.,36 The most common route of contamination is dental caries, inducing successive inflammatory responses in the pulp tissue, ending with pulp necrosis if appropriate therapeutic measures are not adopted. ${ }^{34}$ Having overcome either or both physical and/or biological barriers, establishment of infection will depend upon the survival of microorganisms within the pulp space. ${ }^{34}$

\section{Pulpal response to injuries}

The pulp tissue normally reacts to a biological, physical, or chemical injury, provoking tertiary (reactionary or reparative) dentinal deposition, accompanied by moderate inflammatory cell infiltration. ${ }^{37}$ Fibrosis and premature aging of the pulp may accompany resolution. ${ }^{37}$

Once bacteria invade and colonize the dentin, their removal is very difficult. Although pulpal infection produces an immune response in the dental pulp, the immune response is not enough to eradicate the pathogens. This occurs because immune cells and molecules cannot reach into the dentin effectively, as the dental pulp tissues are entrapped by the dentin and also as a result of restricted vascularization. ${ }^{38}$ One should recall that the pulp consists of a highly vascularized and highly innervated connective tissue, encased into rigid walls, in communication with the periodontium and with the rest of the body only through the apical foramen, apical deltas, and accessory canals. Thus, from a practical clinical point of view, the pulp is an end organ without collateral circulation. ${ }^{34}$

If the pulpal vascular system becomes dysfunctional, pulpal infection typically progresses and causes pulpal disease (ranging from reversible to irreversible pulpitis), which will eventually lead to total necrosis, depending on how host defense mechanisms can cope with the increased numbers of (virulent) bacteria and their products. If left untreated, pulpal disease will spread beyond the apex of the tooth leading to periapical disease. Initially, only the periodontal ligament will be involved in the periapical reaction. However, resorption of cementum 
(and dentin) and breakdown of the alveolar bone ensues and all periodontal tissues end up affected. ${ }^{39}$ It is a cascade reaction which starts with dental caries and then progresses to pulpal disease, pulp necrosis, and periapical disease. The latter may have systemic presentation with clinical signs such as high temperature, malaise, and leukocytosis; in susceptible patients, for whom subacute bacterial endocarditis is a potential risk, there could be lifethreatening implications..$^{34,40,41}$

Bacteria colonizing the root canal damage periradicular tissues; and periradicular inflammation can be observed even before the entire root canal becomes necrotic. ${ }^{42,43}$ As the infection progresses, the cellular infiltrate intensifies and tissue destruction continues with the formation of small abscesses and necrotic foci in the pulp, which eventually leads to total pulp necrosis. ${ }^{44}$

After pulp necrosis, usually as a sequelae of dental caries, the root canal environment provides a selective habitat for the establishment of a mixed microbiota with predominance of anaerobic bacteria. ${ }^{45}$ To exert its pathogenic effects, the root canal microbiota must either invade periradicular tissues or evoke (by their products and/or structural components) a defense response in the host for establishment of apical periodontitis. ${ }^{46}$

Microbial challenge emanating from the root canal system elicits an inflammatory response in periradicular tissues, in an attempt to prevent the spread of the infectious process into bone tissue and beyond. Periradicular diseases can give rise to a multitude of clinical and radiographic presentations and can be regarded as infectious disorders caused by endodontic infections. $38,45,46,47$

\section{Classification of bacteria based on Gram staining}

Bacteria are traditionally classified as gram-positive and gram-negative after Gram staining. Gram-positive bacteria are those whose cell walls have a single thick layer of peptidoglycans. By using Gram staining with crystal violet, the bacteria are stained purple or blue, as they retain the dye even when exposed to alcohol. Gram-negative bacteria are those with a thinner cell wall and a second lipid membrane outside the cell wall, which is exclusively found in these bacteria. In the staining process, the lipid in this outermost membrane is dissolved by alcohol and releases the first dye, crystal violet. At the end of the staining process, the cells are visualized by the second dye, safranin, which gives them a red color. ${ }^{48}$

Figure 1 shows bacterial penetration into dentinal tubules and examples of Gram staining morphology.

Table 1 shows the bacterial genera most commonly found in endodontic infections according to their Gram staining characteristics and gaseous requirements. Some Gram-positive species detected in root canals are strict anaerobes, including Eubacterium, Filifactor, Parvimonas, Peptostreptococcus, Pseudoramibacter and
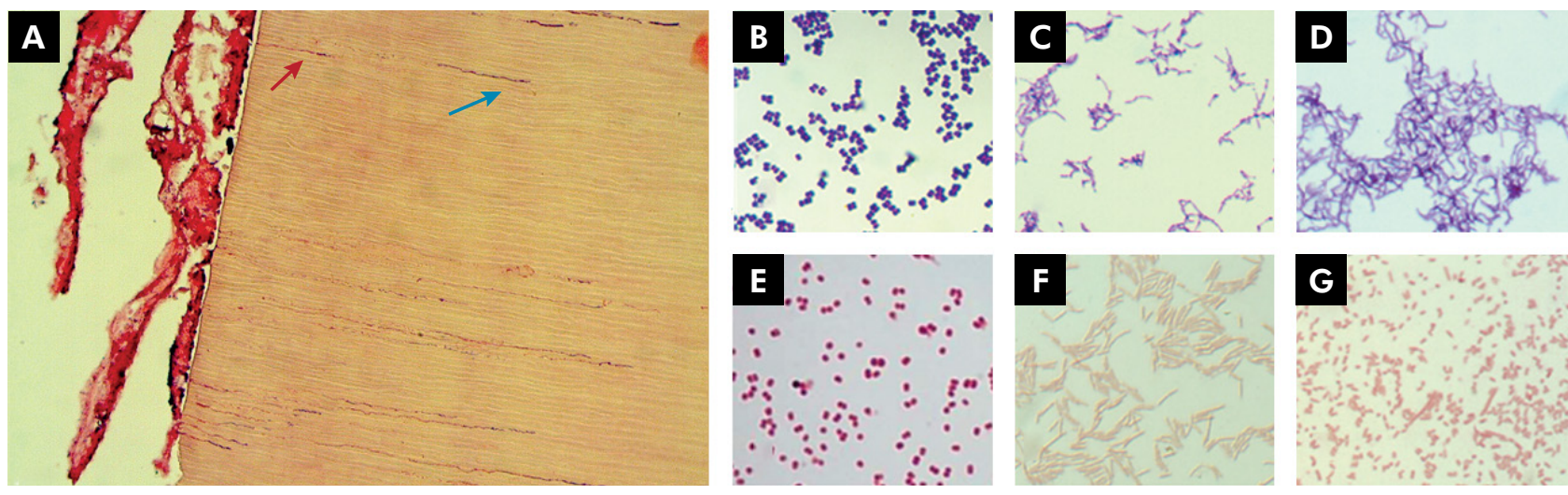

Figure 1. Bacterial penetration into dentinal tubules and examples of Gram staining morphology. A- Histological section of an instrumented root canal (Taylor modification of Brown \& Brenn stain; original magnification $\times 20$ ) showing the root canal wall covered by biofilm and some dentinal tubules clogged with gram-negative bacteria (red arrow) and gram-positive bacteria (purple arrow); B- Gram-positive cocci; C-D- Gram-positive rods; E- Gram-negative cocci; and F-G- Gram-negative rods (Courtesy Dr Jefferson J.C. Marion). 
Table 1. Bacterial genera commonly occurring in endodontic infections according to the Gram-staining characteristics and gaseous requirements.

\begin{tabular}{|c|c|c|}
\hline Bacteria morphology & Obligate anaerobes & Facultative anaerobes \\
\hline \multirow{4}{*}{ Gram-positive cocci } & Finegoldia & Enterococcus \\
\hline & Parvimonas & Gemella \\
\hline & Peptoniphilus & Staphylococcus \\
\hline & Peptostreptococcus & Streptococcus* \\
\hline Gram-negative cocci & Veillonella & Neisseria \\
\hline \multirow{8}{*}{ Gram-positive rods } & Actinomyces & \\
\hline & Eggertella & \\
\hline & Eubacterium & Actinomyces* \\
\hline & Filifactor & Corynebacterium \\
\hline & Lactobacillus & Lactobacillus* \\
\hline & Olsenella & Propionibacterium* \\
\hline & Propionibacterium & \\
\hline & Pseudoramibacter & \\
\hline \multirow{10}{*}{ Gram-negative rods } & Alloprevotella & \\
\hline & Bacteroides & \\
\hline & Camphylobacter & \\
\hline & Dialister & Capnocytophaga \\
\hline & Fretibacterium & Eikenella \\
\hline & Fusobacterium & Haemophilus \\
\hline & Porphyromonas & \\
\hline & Prevotella & \\
\hline & Tannerella & \\
\hline & Treponema & \\
\hline
\end{tabular}

*Some species can also be strict anaerobes.

Propionibacterium. Other Gram-positives are facultative anaerobes, including Actinomyces*, Lactobacillus*, Streptococcus* ("some species can be strict anaerobes), Enterococcus, Gemella and Staphylococcus. ${ }^{910,32}$

Some members of the gram-negative community are strict anaerobes, including Fusobacterium, Porphyromonas, Prevotella, Tannerella and Treponema. Others are facultative anaerobes such as Capnocytophaga, Eikenella, Neisseria, among others. ${ }^{910,32}$

Escherichia coli is a gram-negative, facultatively anaerobic, rod-shaped, coliform bacterium found in the gastrointestinal tracts of humans and other vertebrates, and rarely isolated from root canals. However, it is widely used in laboratories because it is easy and inexpensive to grow, not particularly virulent, and it is an excellent host for producing several proteins. It was one of the first organisms to have its genome sequenced, in 1997. More than 90\% of endotoxin studies were conducted on E. coli LPS. ${ }^{49}$

\section{Bacterial virulence factors}

Bacterial virulence factors include the structural components and products of bacterial metabolism. The latter are responsible for direct damage to pulp tissue, whereas structural components of the bacterial cell, such as lipopolysaccharides (LPS) and lipoteichoic acid (LTA), can injure tissues indirectly by activation of an immune response. ${ }^{50}$

LPS, or endotoxin, is a major constituent of the cell wall of gram-negative bacteria and is secreted in vesicles by growing organisms or released during the disintegration of bacteria after their death. Endotoxin is one of the most important virulence factors involved in the development of periapical inflammation and bone destruction, activating immunocompetent cells and leading to the release of a variety of proinflammatory mediators. Lipid A is the bioactive component of LPS responsible for most of the host's immune response. .1,52,53,54 $^{\prime}$

LTAs are present on the surface of gram-positive cells, such as Enterococcus faecalis, and have adhesive properties, as they adsorb to hydroxyapatite, binding through its lipid portion. They stimulate leukocytes, monocytes, and macrophages to release inflammatory mediators. ${ }^{55}$ Thus, LTA may be associated with resistance to medications used during endodontic treatment, ${ }^{56,57}$ also playing an important role in biofilm formation, providing bacterial resistance to antibiotics or disinfectants. It contributes to the virulence of $E$. faecalis by facilitating aggregation substance formation and plasmid transfer. ${ }^{56}$

LPS and LTA activate the immune system by similar mechanisms. Both bind to CD14, activating Toll-like receptor signaling and inducing the production of proinflammatory cytokines, such as tumor necrosis factor alpha (TNF- $\alpha$ ), interleukin-1 (IL-1), interleukin-8 (IL-8), interleukin-12 (IL-12), and anti-inflammatory cytokines such as interleukin-10 (IL-10). ${ }^{58,59}$ At low concentrations, LPS and LTA stimulate the innate response of the host defense system. At higher levels, they have been related to pain of pulp origin and to periradicular inflammation. . $^{16,60}$ 
Based on the facts and considerations above, it is clear that infection of the root canal system is the primary cause of apical periodontitis. In addition, virulence factors help the bacteria invade the host, cause disease, and evade host defenses, thereby worsening periradicular diseases.

\section{The endodontic microbiota}

Since Miller ${ }^{61}$ demonstrated the presence of bacteria in necrotic pulp tissue, the role of oral microorganisms in the pathogenesis of pulpal and apical periodontitis has become increasingly evident. However, knowledge about the nature of the endodontic microbiota depends upon the recognition of the microorganisms present in the pulp space, which relies on contemporary knowledge and technology. ${ }^{34}$

\section{Methods for microbial detection in root canals}

Currently, there are several methods for microbial identification, including culture- and non-culturebased techniques. Traditionally, microorganisms in endodontic samples have been identified by various cultivation procedures, which rely on isolation, growth, and laboratory identification, using morphology and biochemical tests. However, the prevalence of some oral pathogens could have been underestimated by culture-based techniques as such approaches may fail to grow certain bacteria, especially fastidious anaerobic microorganisms such as spirochetes. ${ }^{49,10,62,63}$

Culture is a widely used method for evaluating the antimicrobial efficacy of root canal procedures against viable bacteria in root canal infection. ${ }^{2}$ Correlations between absence of cultivable bacteria and a favorable treatment outcome have been reported ${ }^{64}$ In order to recover microorganisms from the necrotic pulp and from diseased periapical tissues and study their properties, stringent anaerobic sampling and cultivation techniques are necessary. ${ }^{2}$ Improvements in anaerobic techniques have permitted a more detailed knowledge of the microbiota within the infected root canals and its association with periapical lesions. ${ }^{4,63}$

Advances in molecular techniques have improved the identification of several novel and as-yet-uncultivated bacterial species. Molecular techniques include polymerase chain reaction
(PCR) and its variations (nested PCR, real-time quantitative PCR), cloning and sequencing, and next generation sequencing (NGS). NGS is a high throughput sequencing technology that has enabled the parallel sequencing of several microbiological samples by PCR amplification of a phylogenetic marker, the $16 \mathrm{~S}$ rRNA. It also provides the most accurate detection of abundant and rare members of the microbial community. Furthermore, an advantage of this method is that it does not require laborious cloning to obtain microbial sequences. ${ }^{65}$ All of the above-mentioned techniques are based on bacterial identification through the $16 \mathrm{~S}$ rRNA gene, a region of bacterial DNA present in all microorganisms that is well preserved and very specific to each species. ${ }^{63}$

Unlike the techniques based on the 16S rRNA gene, the checkerboard DNA-DNA hybridization or DNADNA hybridization was introduced for hybridizing large numbers of DNA samples against large numbers of DNA probes on a single support membrane. ${ }^{66}$ This method is fast, has adequate sensitivity, and it is relatively inexpensive, overcoming several limitations of microbial culture, allowing the study of the communities present in clinical samples. ${ }^{66,67}$

Molecular methods overcome the limitations of culture-dependent methods; however, despite the inherent limitations of each method, the combined results of both cultural and molecular studies are necessary to improve the understanding of the endodontic microbiota. ${ }^{68}$ For example, the sensitivity of microbial culture is approximately $10^{4}$ to $10^{5}$ cells for target species using nonselective media and $10^{3}$ using selective media, while for PCR it ranges from 10 to $10^{2}$ cells, depending on the technique used. Nested PCR brings the detection limit down to about 10 cells. ${ }^{69}$ The detection limits of the checkerboard DNA-DNA hybridization method ranges from $10^{3}$ to $10^{4} \cdot 63,66,70$

\section{Factors related to the composition of the root canal microbiota}

The major ecological factors that define the composition of the root canal microbiota are the availability of nutrients, redox potential variability, and bacterial interactions. ${ }^{5,6,32,34,71}$ Bacterial interactions might be the key element to the growth and survival of organisms in their habitat. On the other hand, 
bacterial interaction can also have an effect on the microbial population itself, inhibiting the growth of particular species and perhaps increasing the chances of the host to cope with the infective agent and to restore health. Other factors involved are $\mathrm{pH}$ level, temperature, and host defense mechanisms. 5,6,32,34,71

It has been reported that there is a difference between the microbiota of a root canal subjected to any source of oral contamination for some time and the microbiota of closed canals. In closed canals, the microbiota is predominantly anaerobic, while in open canals the recovered/detected microorganisms are mostly facultative anaerobes. . $^{34,45,47,72}$ Moreover, anaerobes are also more frequently detected in root canal samples from clinically symptomatic teeth, $4,7,10,32,45,47,67,72-78$ which have a bacterial community profile that is significantly different from asymptomatic (chronic) lesions. This has also been observed for teeth with primary versus post-treatment apical periodontitis. 7,910,32,77,79-81

In addition, the bacterial community profile exhibits a high interindividual variability and there are significant geographic differences in the composition of the endodontic microbiota, which may have implications in terms of efficacy of antimicrobial protocols used in different countries. ${ }^{10,32}$

\section{Overall microbial composition of the root canal}

Similarly to the oral cavity, over 500 different bacterial species or phylotypes have already been detected in infected root canals by culture or by molecular methods such as 16S rRNA gene sequencing or metagenomic sequencing. Bacteria are the most commonly found microorganisms in root canals, belonging to 20 phyla according to present knowledge. ${ }^{32}$

Table 2 shows some of the microorganisms isolated/ detected from root canals according to their phyla. Of the major reported phyla, Firmicutes, Fusobacteria, and Bacteroidetes were the most abundant in acute infections, while Firmicutes, Bacteroidetes, and Actinobacteria were the most abundant in chronic infections. ${ }^{76,77,81} \mathrm{In}$ addition, fungi, yeasts, ${ }^{10,80,82-86}$ viruses, ${ }^{87-90}$ and Archaea ${ }^{71,91}$ were also detected in root canals.

These microorganisms can be found suspended in the lumen of the root canal (planktonic form) or adhered to the walls of the root canal, forming a biofilm (sessile form). They can penetrate into dentinal tubules and into lateral, secondary, and accessory canals. They can be found between the gutta-percha and the root canal walls, and they can also form biofilms in the extraradicular region. The colonization of these sites is directly related to the time of infection and to the composition of the microbiota. ${ }^{32}$

\section{Classification of endodontic infections}

Endodontic infections can be classified according to their anatomical location (intraradicular or extraradicular infection) and to how long it took microorganisms to reach the root canal (primary, secondary, or persistent infection). Usually, primary and secondary/persistent endodontic infections are located intraradicularly, and may originate in extraradicular infections if left untreated or inadequately treated., ${ }^{9,10,32}$

Primary infected root canals are untreated canals where microorganisms were able to access and colonize the pulpal tissue and impair its function. Their microbial profile consists of 10-30 species per canal, 9,10,32,92 and the species present in the apical region may have a major role in the pathogenesis of apical periodontitis.

Fusobacterium, Porphyromonas, Prevotella, Parvimonas, Tannerella, Treponema, Dialister, Filifactor, Actinomyces, Olsenella, and Pseudoramibacter predominated in the canals. Some facultative or microaerophilic streptococci are also commonly found in primary infections. $9,10,32$

Persistent/secondary infected root canals are usually associated with post-treatment apical periodontitis, which indicates that there was a failure in endodontic treatment. In this case, microorganisms may have tolerated the chemomechanical procedures (persistent infection) or invaded the canal via coronal leakage of the root filling (secondary infection). ${ }^{79,10,32,85}$

The microbiota found in cases of endodontic failure is composed of a more restricted group of species when compared to primary infections. Canals apparently well treated have been shown to harbor fewer than five species. On the other hand, teeth with unsatisfactory root filling may harbor 10 to 30 species, a number similar to that of primary infections. ${ }^{9,32}$

Facultative anaerobic and gram-positive bacteria predominated in canals with endodontic treatment failure, which may be due to increased resistance 
- Etiologic role of root canal infection in apical periodontitis and its relationship with clinical symptomatology

Table 2. Microorganisms most commonly isolated/ detected from root canals distributed according to the phyla.

\begin{tabular}{|c|c|c|c|c|c|c|}
\hline Firmicutes & Actinobacteria & Fusobacteria & Proteobacteria & Spirochaetes & Bacteroidetes & Synergistetes \\
\hline Dialister pneumosintes & $\begin{array}{l}\text { Actinomyces } \\
\text { gerencseriae }\end{array}$ & $\begin{array}{l}\text { Fusobacterium } \\
\text { necrophorum }\end{array}$ & $\begin{array}{c}\text { Campylobacter } \\
\text { gracilis }\end{array}$ & $\begin{array}{l}\text { Treponema } \\
\text { amylovorum }\end{array}$ & $\begin{array}{l}\text { Alloprevotella } \\
\text { tannerae }\end{array}$ & \\
\hline Dialister invisus & $\begin{array}{l}\text { Actinomyces } \\
\text { israelii }\end{array}$ & $\begin{array}{c}\text { Fusobacterium } \\
\text { nucleatum ssp } \\
\text { nucleatum }\end{array}$ & $\begin{array}{l}\text { Campylobacter } \\
\text { rectus }\end{array}$ & $\begin{array}{l}\text { Treponema. } \\
\text { denticola }\end{array}$ & $\begin{array}{l}\text { Porphyromonas } \\
\text { endodontalis }\end{array}$ & $\begin{array}{l}\text { Pyramidobacter } \\
\text { piscolens }\end{array}$ \\
\hline Eggerthella lenta & $\begin{array}{l}\text { Actinomyces } \\
\text { naeslundii }\end{array}$ & $\begin{array}{l}\text { Fusobacterium } \\
\text { nucleatum ssp } \\
\text { polymorphum }\end{array}$ & $\begin{array}{l}\text { Eikenella } \\
\text { corrodens }\end{array}$ & $\begin{array}{c}\text { Treponema } \\
\text { lecithinolyticum }\end{array}$ & $\begin{array}{l}\text { Porphyromonas } \\
\text { gingivalis }\end{array}$ & \\
\hline Enterococcus. faecalis & $\begin{array}{l}\text { Actinomyces } \\
\text { odontolyticus }\end{array}$ & & $\begin{array}{l}\text { Haemophilus } \\
\text { aphrophilus }\end{array}$ & $\begin{array}{l}\text { Treponema } \\
\text { maltophilum }\end{array}$ & $\begin{array}{l}\text { Prevotella } \\
\text { denticola }\end{array}$ & \\
\hline Filifactor alocis & $\begin{array}{l}\text { Actinomyces } \\
\text { viscosus }\end{array}$ & & & $\begin{array}{l}\text { Treponema } \\
\text { medium }\end{array}$ & $\begin{array}{l}\text { Prevotella } \\
\text { intermedia }\end{array}$ & \\
\hline Finegoldia magna & $\begin{array}{c}\text { Propionibacterium } \\
\text { acnes }\end{array}$ & & & $\begin{array}{c}\text { Treponema } \\
\text { pectinovorum }\end{array}$ & $\begin{array}{c}\text { Prevotella } \\
\text { melaninogenica }\end{array}$ & \\
\hline Parvimonas micra & $\begin{array}{l}\text { Propionibacterium } \\
\text { propionicum }\end{array}$ & & & $\begin{array}{l}\text { Treponema } \\
\text { socranskii }\end{array}$ & $\begin{array}{l}\text { Prevotella } \\
\text { nigrescens }\end{array}$ & \\
\hline Peptoniphilus asaccharolyticus & Slackia exigua & & & $\begin{array}{l}\text { Treponema } \\
\text { vincentii }\end{array}$ & $\begin{array}{l}\text { Tannerella } \\
\text { forsythia }\end{array}$ & \\
\hline
\end{tabular}

Peptostreptococcus anaerobius

Pseudoramibacter alactolyticus

Selenomonas sputigena

Streptococcus anginosus

Streptococcus constellatus

Streptococcus intermedius

Streptococcus mitis

Streptococcus sanguis

Veillonella parvulla

to instrumentation and to antiseptic agents. $5,6,82,85$ According to Molander et al., ${ }^{82}$ facultative anaerobes, especially gram-positive ones, can survive in a quiescent phase with low metabolic activity for some time, and factors such as coronal leakage during or after root canal treatment can change the nutritional conditions and contribute to bacterial growth.

E. faecalis, a facultative gram-positive bacterium, is capable of surviving in an environment with scant availability of nutrients and minimal commensality with other bacteria. ${ }^{83,93}$ It presents 
different virulence and resistance mechanisms, which hinder its eradication from root canals. ${ }^{22}$ An important collagen-binding protein of $E$. faecalis microbial surface components is Ace (adhesion of collagen from $E$. faecalis), ${ }^{93}$ which is related to its ability to invade dentinal tubules and adhere to collagen in the presence of human serum. ${ }^{94,95}$

Streptococcal species are also frequently found in root canals of teeth with post-treatment disease. Other bacterial species, including anaerobic bacteria such as Parvimonas micra, Propionibacterium species and Pseudoramibacter alactolyticus are commonly reported in persistent intraradicular infections. Candida species are more frequently found in root canals of teeth with endodontic failure than in those with primary infections $.9,10,32,79,85$

Extraradicular infections are mostly caused by intraradicular infections. They are characterized by apical abscesses and extraradicular biofilms. However, there are also independent extraradicular infections, such as apical actinomycoses, caused by Actinomyces spp. and Propionibacterium spp., requiring periapical surgery for their resolution. ${ }^{32,36,96}$

Apical periodontitis may be acute or chronic, depending on several factors. Acute infection is usually caused by a community of highly virulent bacteria, probably due to the presence of species with greater virulence or to the synergism between species and is characterized by a high concentration of bacteria and tissue invasion, together with decreased host resistance ${ }^{46}$ Chronic apical periodontitis, by contrast, is usually associated with low virulence of the bacterial community involved. Bacterial persistence in the root canal system may be related to its organization in biofilms, not allowing for host defense due to the anatomical location of the infection. ${ }^{46}$

Acute apical abscess is the most common form of extraradicular infection. Microbial communities present in acute apical abscesses are complex, with a predominance of strict anaerobic microorganisms (approximately $90 \%$ of the isolates), mainly gramnegative bacilli, including Fusobacterium, Prevotella, Porphyromonas, Dialister, and Treponema, and grampositive cocci. They are polymicrobial infections where the occurrence of strict anaerobes is 3 to 4 times greater than that of facultative anaerobes. ${ }^{76,78,97,98,99}$ However, although the concentration of strict anaerobes is higher in periapical abscesses, their diversity is lower than that found in the root canals of periapical abscesses. ${ }^{98,99}$

Chronic apical abscess is characterized as an inflammation in the periapical region with formation and discharge of pus slowly through a fistula, recognized as a pathognomonic sign of this lesion. Radiographically, there are radiolucent signs of apical bone destruction, however without significant discomfort for the patient. ${ }^{100}$ The endodontic microbiota of this pathology has been scarcely characterized in the literature, probably due to its low prevalence (between 9.7\% and $18.1 \%) .{ }^{101}$ Rôças et al. ${ }^{75}$ used checkerboard DNA-DNA hybridization to identify microorganisms in the root canals of nine patients diagnosed with chronic apical abscess. Porphyromonas endodontalis (9/9 - 100\%), Dialister invisus (8/9 - 89\%), Parvimonas micra (7/9-78\%), and Solobacterium moorei (7/9 - 78\%) were the most prevalent species in these cases. Tennert et al., ${ }^{102}$ after sequencing the 16S rRNA genes of isolated microorganisms, reported the presence of Anaerococcus prevotii, Atopobium rimae, Dialistes invisus, and Fusobacterium nucleatum.

Bacterial biofilm is a community of microcolonies of bacterial cells involved in an extracellular matrix of polysaccharides, adhered to a solid substrate wet or liquid medium, from which bacteria can obtain their nutrients. Biofilm is a form of protection against bacterial development in hostile environments. It can be formed by one or multiple species. ${ }^{96,103,104,105,106,107}$

Periradicular dental biofilm is characterized by microorganisms adhered to cementum and/or dentin in the apical portion of the root, surrounded by an external polysaccharide layer known as glycocalyx, which forms an intermicrobial matrix. The structure of the polysaccharide matrix that surrounds the biofilm limits the access of defense molecules (antibodies and complement) and of phagocytic cells (macrophages and neutrophils). ${ }^{108}$ The prevalence of intraradicular bacterial biofilms is high, whereas extraradicular biofilms are considered rare and are normally dependent on intraradicular infections. ${ }^{106}$

Bacteria in biofilm differ phenotypically from their planktonic form, since a number of genes are regulated to optimize their phenotypic properties in 
a given environment. ${ }^{107}$ Clinically, one of the main characteristics of bacterial biofilms is their greater resistance to antimicrobial agents. ${ }^{109}$

Figure 2 illustrates the radiographic aspects and microbiological findings observed in each type of infection. There is a great diversity of microbial colonies in primary intraradicular infections (Figure 2, A-B) and a lower diversity in secondary ones (Figure 2, C-D). A large diversity of microbial colonies with a predominance of black-pigmented bacteria can be found in acute periapical abscesses (extraradicular infections) (Figure 2, E-F), whereas endodontic treatment failures may be due to the presence of extraradicular apical biofilms, on which microorganisms such as Actinomyces israelii may be present (Figure 2, GH).

In summary, although the infectious nature of endodontic pathosis has been established for many decades, with the development of modern microbiological diagnostic techniques, the composition of these infections has been improved and redefined.

\section{The key role of endotoxin}

All gram-negative bacteria, and only these microorganisms, have a differentiated external cell membrane with hydrophobic constituents composed of polysaccharides (sugar polymers), lipids (complexes containing fatty acids), and proteins. This structure is called LPS or endotoxin, highlighting the main components and biological effects of the molecule. ${ }^{3}$

Endotoxins are secreted into vesicles during the bacterial growth phase or released during cell death. They are also released when the cell is chemically treated to remove LPS. LPS represents the major antigenic surface of gram-negative bacteria, presenting microbiological and immunological significance. ${ }^{51,52}$

Approximately $75 \%$ of the cell surface of gramnegative bacteria is composed of this molecule, which is essential for cell growth, decrease in membrane permeability, and structural integrity and stability, as well as for protection against external damage. ${ }^{52,110}$

Endotoxins are heat-stable and, therefore, usual sterilization processes are ineffective for
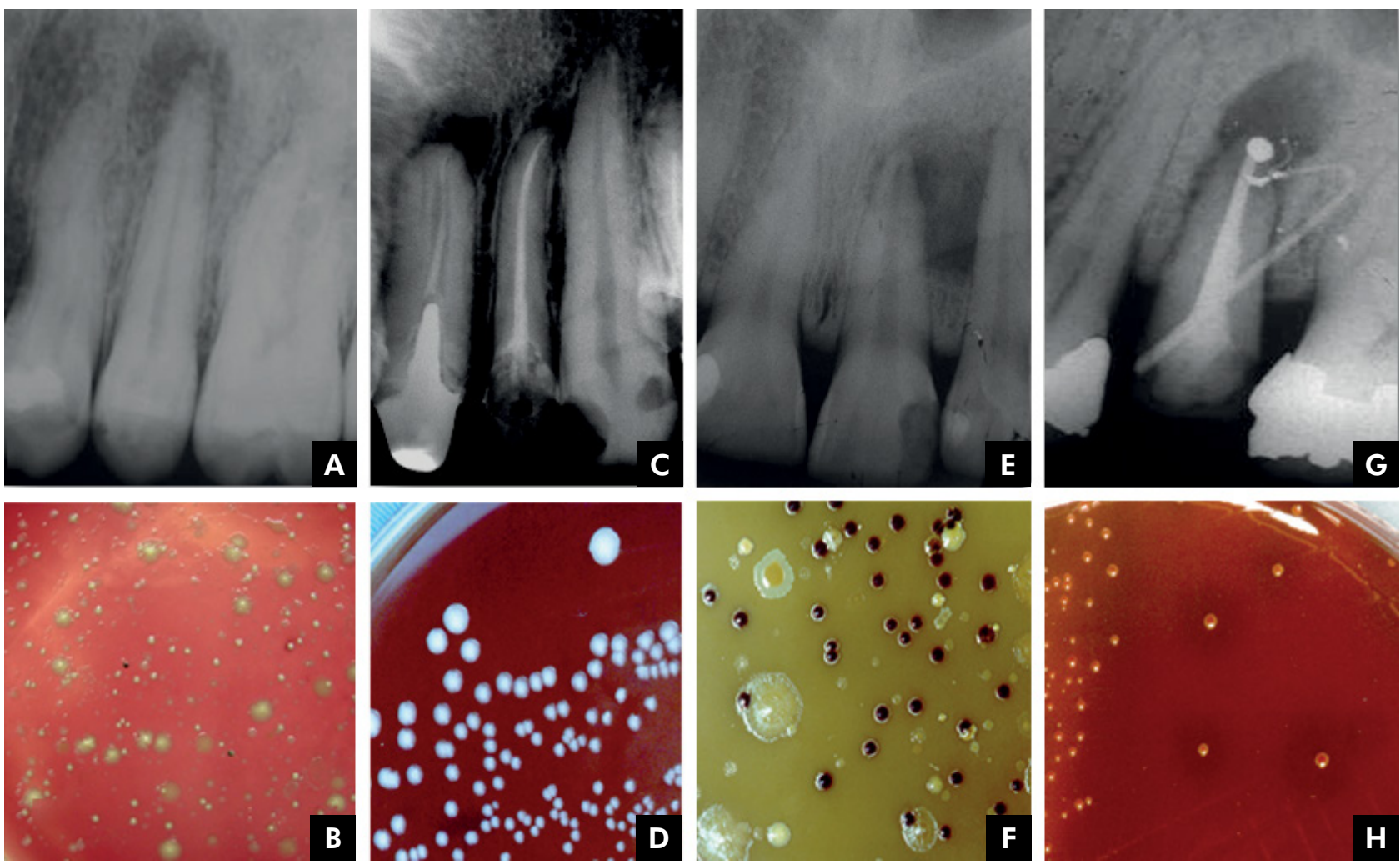

Figure 2. Radiographic aspects and microbial culture plates of different types of endodontic infections. A-B - Primary infection; C-D - Secondary infection; E-F- Periapical abscess; and G-H- Apical Biofilm 
their destruction. ${ }^{111}$ To degrade them chemically, strong acids or bases or pyrolysis must be used, and different heating protocols are known: $180^{\circ} \mathrm{C}$ for 3 hours, ${ }^{111,112} 200^{\circ} \mathrm{C}$ for 4 hours,,$^{113}$ or $250^{\circ} \mathrm{C}$ for 3 hours according to the Cambrex/Lonza manual. Other processes that lead to the inactivation of endotoxins are ionizing radiation and treatment with polymyxin B. In endodontic therapy, hydroxyl ions present in the calcium hydroxide paste can hydrolyze LPS, degrading lipid A and neutralizing its residual effect after cell lysis. ${ }^{54,114}$

LPS is known to be the most toxic constituent of bacterial endotoxin, having no structural homologue among multicellular organisms. ${ }^{115}$

In general, bacterial LPS are composed of three structural domains: lipid A, core, and repeating O-antigen. ${ }^{16,117,118}$ The lipid A moiety exerts most of the endotoxic activities, being regarded as the endotoxic principle of LPS. ${ }^{116}$ The chemical structure of lipid A is composed of fatty acids with 15 to 17 carbon atoms, linked to two amino-sugar molecules (glycosamines), to which two phosphate radicals are bound, and a protein residue bound to the phosphate radicals. The positions of the phosphate radicals, as well as the number, type, and site of bonds seem to determine the inflammatory potential of different LPS. ${ }^{22}$

Polysaccharide moiety is a potent antigen that can stimulate antibody formation even at submicrogram concentrations. ${ }^{119}$ The recognition of LPS occurs through lipid A, which in turn activates different intracellular signaling pathways through its binding to proper receptors, according to the structure of the acyl chain. ${ }^{120}$ The major receptors are located in the cell membrane of monocytes, called Toll-like receptors 4 (TLR4). ${ }^{121,122}$

Studies have shown that lipid A can vary among different bacterial species, depending on the number of phosphate groups and on the amount and position of fatty acids in the molecule. ${ }^{53,120,123}$ These variations are closely related to the change in TLR4 signaling and, consequently, to their immunostimulatory effects. ${ }^{18,120,124}$ TRL-4 mutations are likely to influence susceptibility to gram-negative infection, or the course of infection once it is established, as they block LPS signaling, whereas overexpression greatly increases LPS signaling. ${ }^{115}$ Moreover, changes in the microenvironment, such as hemin concentration and temperature, can structurally alter this bioactive portion. ${ }^{125}$

LPS structure is remarkably heterogeneous among bacterial species, thus evoking different patterns of inflammatory response. The LPS molecule can also vary among different strains of single species and, consequently, exhibit different inflammatory potentials. ${ }^{53,18,126}$

More than $90 \%$ of endotoxin studies have been conducted on enterobacterial LPS, ${ }^{49}$ of which Escherichia coli LPS is the best known. LPS from gram-negative bacteria such as Prevotella and Porphyromonas isolated from the oral cavity are able to produce classic manifestations that are less damaging to host tissues than those from E. coli. ${ }^{127}$ On the other hand, Fusobacterium spp. LPS presents a similar structure to that of gram-negative enteric bacilli, ${ }^{128}$ contributing to the high virulence of this microorganism. ${ }^{127}$ According to Martinho et al., ${ }^{126}$ Fusobacterium nucleatum induces a greater expression of IL-1 $\beta$ and TNF- $\alpha$ cytokines compared to Porphyromonas gingivalis. These two bacteria have different patterns of macrophage activation, which may contribute to the immunopathogenesis of apical periodontitis.

LPS is essential for bacterial survival because it protects the bacterium from host defense cell stimuli. ${ }^{129}$ It has many biological activities including fever induction, adjuvant activity, Schwartzman reaction, cytotoxicity, blood clotting, and fibrinolysis, among others. LPS can also stimulate production of bradykinin, which is a potent pain mediator. ${ }^{130}$

Siqueira Junior and Rôças ${ }^{46}$ mention several biological effects of LPS, as follows:

a) Activation of macrophages/monocytes with consequent synthesis and release of proinflammatory cytokines (IL-1 $\beta$, IL-6, CXCL8 or IL-8, TNF- $\alpha$ ), prostaglandins, nitric oxide, and oxygen-derived free radicals. These substances are chemical mediators of inflammation and most of them can stimulate bone resorption;

b) Activation of the complement system. Some products of complement activation are chemotactic to inflammatory cells (C5a), act as opsonins (C3b), and can increase vascular permeability (C3a and $\mathrm{C} 5 \mathrm{a}$ ).

c) Activation of the Hageman factor, the first step of the intrinsic pathway of coagulation, triggering the 
coagulation cascade or the production of bradykinin, an important chemical mediator of inflammation;

d) Induction of the expression of leukocyte adhesion molecules in endothelial cells, which are important in the early stages of inflammation;

e) Stimulation of osteoclast differentiation and bone resorption, particularly via interactions with TLR4 in osteoblast lineage cells. LPS induces RANKL expression in osteoblasts and stimulates these cells to secrete interleukin (IL)-1, IL-6, prostaglandin E2 (PGE2), and TNF- $\alpha$, each of which is known to induce osteoclast activity and differentiation.

f) LPS may be mitogenic to B lymphocytes and epithelial cells.

g) LPS can stimulate naive B cells in the absence of $\mathrm{T}$ helper cells. At low concentrations, LPS stimulates specific antibody production. At high concentrations, this molecule can cause nonspecific polyclonal activation of B cells.

h) It has been recently demonstrated that trigeminal afferent neurons express the TLR4 and CD14 receptor complex and that LPS activation of TLR4/CD14 may trigger intracellular signaling cascades, leading to peripheral release of neuropeptides and central nociceptive neurotransmission. Hence, it is assumed that one of the pain mechanisms associated with bacterial infectious processes could result from direct effects of LPS on sensory fibers via interaction and direct activation of the TLR4/CD14 complex.

LPS may evoke pain through activation of the Hageman factor or through neurotoxic properties when acting on presynaptic nerve terminals, direct sensitization of nociceptors, sensitization and up-regulation of the transient receptor potential cation channel, subfamily V, member 1 (TRPV1). ${ }^{18}$

LPS concentrations found in infected root canals seem to promote a direct sensitization of receptors that activate the pain mechanism associated with bacterial infections, also sensitizing trigeminal sensory neurons. ${ }^{131,132}$

The presence of endotoxin has been reported in samples taken from vital pulp, ${ }_{1}^{13}$ irreversible pulpitis, ${ }_{13}^{13}$ necrotic pulp, $11,12,13,15,16,17,20,25,28,29,30,113,131,133,134,135,136,137,138,139$ root canals of teeth with endodontic failure, ${ }^{19,20,26,132}$ and

Table 3. Total endotoxin levels in initial samples from root canal reported in previous studies.

\begin{tabular}{|c|c|c|c|}
\hline Author & Pulpal / Periodontal tissue status & LAL Method & $\begin{array}{c}\text { Endotoxin } \\
\text { concentration }\end{array}$ \\
\hline \multirow{2}{*}{ Schein and Schilder $(1975)^{13}$} & Vital pulp / healthy periodontium & Gel clot & $0.007 \mu \mathrm{g} / \mathrm{mL}$ \\
\hline & Irreversible pulpitis / healthy periodontium & Gel clot & $0.075 \mu \mathrm{g} / \mathrm{mL}$ \\
\hline Schein and Schilder $(1975)^{13}$ & \multirow{18}{*}{ Pulp necrosis / apical periodontitis } & Gel clot & $0.192 \mu \mathrm{g} / \mathrm{mL}$ \\
\hline Jacinto et al. $(2005)^{15}$ & & QCL & $18016.50 \mathrm{EU} / \mathrm{mL}$ \\
\hline Vianna et al. $(2007)^{133}$ & & QCL & $151.61 \mathrm{EU} / \mathrm{mL}$ \\
\hline Martinho and Gomes $(2008)^{16}$ & & QCL & $323.27 \mathrm{EU} / \mathrm{mL}$ \\
\hline Gomes et al. 2009(113) & & QCL & $212.23 \mathrm{EU} / \mathrm{mL}$ \\
\hline Martinho et al. $(2010 a)^{11}$ & & TKA & $9.19 \mathrm{EU} / \mathrm{mL}$ \\
\hline Martinho et al. $(2010 b),{ }^{134}(2012),{ }^{17}(2014)^{25}$ & & TKA & $7490.00 \mathrm{pg} / \mathrm{mL}$ \\
\hline Martinho et al. $(2011 b)^{141}$ & & QCL & $34.20 \mathrm{EU} / \mathrm{mL}$ \\
\hline Martinho et al. $(2011 b)^{141}$ & & $\mathrm{KQCL}$ & $7.49 \mathrm{EU} / \mathrm{mL}$ \\
\hline Martinho et al. $(2011 b)^{141}$ & & TKA & $9.19 \mathrm{EU} / \mathrm{mL}$ \\
\hline Oliveira et al. $(2011)^{135}$ & & KQCL & $192.37 \mathrm{EU} / \mathrm{mL}$ \\
\hline Gomes et al. $(2012)^{20}$ & & TKA & $7.49 \mathrm{EU} / \mathrm{mL}$ \\
\hline Xavier et al. $(2013)^{136}$ & & KQCL & 153.13 EU/mL \\
\hline Marinho et al. $(2014)^{137}$ & & TKA & $18.70 \mathrm{EU} / \mathrm{mL}$ \\
\hline Marinho et al. $(2015)^{29}$ & & TKA & $32.43 \mathrm{EU} / \mathrm{mL}$ \\
\hline Herrera et al. $(2015)^{30}$ & & TKA & $21.83 \mathrm{EU} / \mathrm{mL}$ \\
\hline Cardoso et al. $(2015)^{131}$ & & $\mathrm{KQCL}$ & $10.92 \mathrm{EU} / \mathrm{mL}$ \\
\hline Herrera et al. $(2017)^{139}$ & & TKA & $27.72 \mathrm{EU} / \mathrm{mL}$ \\
\hline Endo et al. $(2012),{ }^{19}$ Gomes et al. $(2012)^{20}$ & Previous root canal treatment / apical periodontitis & TKA & $3.96 \mathrm{EU} / \mathrm{mL}$ \\
\hline Duque et al. $(2018)^{140}$ & Vital pulp / chronic periodontal disease & TKA & $0.10 \mathrm{EU} / \mathrm{mL}$ \\
\hline
\end{tabular}

QCL: Chromogenic endpoint assay (Quantitative chromogenic LAL); TKA: Turbidimetric kinetic assay; KQCL: Chromogenic kinetic assay. 
from root canals of teeth associated with periodontal disease. ${ }^{140}$ Table 3 shows some of the endotoxin levels reported in initial samples collected from the root canals.

LPS have been detected in $100 \%$ of root canals with necrotic pulp, with significantly higher levels in symptomatic teeth. ${ }^{12,15,20,141}$ Moreover, even though LPS levels were higher in primary endodontic infections than in secondary/persistent infections, endotoxins were detected in all samples. ${ }^{20}$ This shows that endotoxins are extremely strong stimulators of inflammatory reactions, even at low concentrations.

There is a correlation between higher levels of endotoxins and a greater area of bone destruction in periapical tissues, ${ }^{142}$ as well as with the presence of specific clinical features found in primary endodontic infections. ${ }^{20,46}$ Increased endotoxin levels in infected root canals may be associated with the severity of periapical disease, as well as with the development of clinical symptoms. ${ }^{20}$

Clinical endodontic researchers have investigated not only bacterial LPS in infected root canals, but also correlated higher endotoxin levels with clinical signs, symptoms, and radiographic findings.

\section{Interplay of infectious/endotoxic contents with inflammatory mediators and clinical symptomatology}

\section{The role of cytokines}

Periapical immune response is a second line of defense that seeks to localize the infection of the root canal system by confining it and preventing its dissemination and systemic involvement. ${ }^{2}$ This immune response is initially comparable to the pulpal response to microbial infection, characterized by a cell infiltrate of polymorphonuclear neutrophils (PMNs) and monocytes, with the subsequent additional feature that the periradicular bone is destroyed. The intensity of bacterial invasion of periradicular tissues depends on the number of pathogenic bacteria and on their degree of virulence. ${ }^{2}$ Once bacteria and their virulence factors come into contact with periradicular tissues, they stimulate the synthesis and expression of different mediators that will attract inflammatory cells to the area. ${ }^{17}$ These factors, depending on host resistance, may stimulate the development of an acute inflammatory response (acute apical periodontitis or acute periradicular abscess), or a chronic response (chronic apical periodontitis or chronic periradicular abscess). ${ }^{46}$ The destruction of periapical tissues seems to be mainly indirect via host-derived stimuli rather than by the direct effects of bacteria on the bone.

Periapical immune response is predominantly a reaction to bacterial infection present in necrotic root canals. ${ }^{46,143,144}$ Immunocompetent cells settle in periapical areas in an attempt to prevent the spread of the infectious microbiota. ${ }^{17}$ Among these cells, macrophages are the defense cells responsible for the rapid recognition of pathogens and rapid presentation of lymphocytes and other cells of the immune system. ${ }^{17}$ Macrophages are stimulated predominantly by the bacterial endotoxin. ${ }^{12,132}$ Lymphocytes express different sets of inflammatory cells, proinflammatory and immunoregulatory cytokines and chemokines, which are considered important mediators in periapical immune response to infection. ${ }^{132,143}$

Among the various host degradative pathways, considerable interest has been focused on the study of cytokines, not only because of their role in regulating the humoral immune system and in cellular responses against invasive bacteria, but also as mediators of periapical tissue destruction. ${ }^{145}$

Inflammatory cytokines produced from host cells (e.g., monocytes/ macrophages) reflect root canal conditions and determine the local immune process within the periapical environment. ${ }^{29}$ After the macrophage and PMN activation by bacterial components, a cascade of proinflammatory cytokines, including IL-1 $\alpha$, IL-1- $\beta$, and TNF $\alpha$, is triggered. ${ }^{144}$

Cytokines are small signaling molecules that mediatehost responses to infection, inflammation, and trauma. Proinflammatory cytokines initiate or enhance systemic inflammation while anti-inflammatory cytokines reduce inflammation and promote healing. ${ }^{144}$ Examples of proinflammatory cytokines include IL-1 and TNF- $\alpha$, whereas IL-10 is an important antiinflammatory cytokine. Some cytokines can have both proinflammatory and anti-inflammatory properties, such as IL-6, as it can inhibit TNF- $\alpha$ and IL-1 and activate IL-10 at the same time. Cytokines work with each other in a homeostatic network regulation to prevent the constant state of inflammation. ${ }^{144}$ 


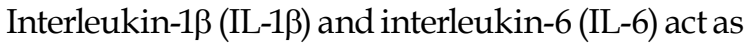
proinflammatory cytokines during apical periodontitis, initiating or intensifying systemic inflammation. ${ }^{144,146}$ In addition, they also stimulate osteoclast differentiation and bone resorption in chronic apical periodontitis, inducing the secretion of chemokines during the destruction of periodontal tissues. ${ }^{146}$

On the other hand, the reactions provoked in the host organism by proinflammatory cytokines can be prevented by suppressing the activity of these cytokines through the activity of anti-inflammatory cytokines, such as interleukin 4 (IL-4), interleukin 10 (IL-10), IL-13, and the transforming growth factor beta (TGF- $\beta$ ) ${ }^{146}$

Proinflammatory cytokines, such as IL-1 $\beta$, IL-2, IL-8, IL-17, IFN-y, and TNF- $\alpha$, are detected in the interstitial fluid of periapical lesions, where the high concentration of bacteria found in root canal infection was correlated with a higher rate of detection of proinflammatory cytokines. ${ }^{147,148}$

Gram-negative bacterial species tend to induce a greater proportion of TNF- $\alpha$, but other cytokines, for example IL-1 $\beta$, IL-6, IL-8, and IL-10, increase their levels during the course of endodontic infection. ${ }^{144}$

TNF- $\alpha$, IL-1 $\beta$, and IL- 6 are examples of important cytokines in the acute phase of inflammation. ${ }^{14,148} \mathrm{On}$ the other hand, LTA, present in gram-positive bacteria, has pathogenic properties similar to those of LPS, ${ }^{21,22}$ resulting in well-known injuries to the dental pulp and periapical tissues. Overall, both LPS and LTA are able to potently activate monocytes/macrophages, causing rapid release of cytokines at periradicular sites related to tissue destruction. ${ }^{21,22}$ However, by comparing the cytokines released by LTA in immune cells with the cytokine released by LPS of gram-negative bacteria, LTA has a power that is 100 to 1,000 times lower than that of LPS. ${ }^{144}$ While LPS is a potent inducer of proinflammatory cytokines and IL-10, LTA exhibits less induction of proinflammatory cytokines and does not induce IL-12 and the subsequent formation of IFN$\gamma_{1}^{149,150}$ which can be explained by the use of different TRLs. ${ }^{149}$ TRL2 appears to be the primary mediator of the innate immune response to the LTA of several gram-positive bacteria ${ }^{151}$ and is highly induced in inflamed dental pulps. ${ }^{152,153}$

TNF- $\alpha$ is the cytokine most abundantly detected in endodontic infection. ${ }^{29,144}$ TNF- $\alpha$ is a potent immune mediator of acute and chronic inflammatory responses, with the potential to increase bone resorption. ${ }^{154}$ It is considered the main mediator of the acute inflammatory response induced by gram-negative bacteria and other infectious microorganisms. LPS is the most important stimulus to activate the production of TNF by macrophages, although activated T cells, $\mathrm{NK}$, and mast cells can also secrete this cytokine. IFN- $\gamma$ produced by $\mathrm{T}$ and NK cells increases the synthesis of TNF by LPS-stimulated macrophages. ${ }^{155}$

TNF- $\alpha$ stimulates the production of collagenase and prostaglandin $\mathrm{E}_{2}\left(\mathrm{PGE}_{2}\right)$, factors related to the induction of chemokines, cytokines, cell adhesion molecules, and bone resorption. ${ }^{17} \mathrm{PGE}_{2}$ can induce or inhibit IL-6, another proinflammatory cytokine that stimulates osteoclast differentiation and bone resorption in chronic apical periodontitis. ${ }^{17}$ IL- 6 can also induce or inhibit $\mathrm{PGE}_{2}$, depending on the duration of the lesion, bacterial load, stimulated signaling pathways, and cytokines. ${ }^{17} \mathrm{PGE}_{2}$ was directly and indirectly related to most of the inflammatory and destructive alterations in apical lesions, such as vasodilation, increased vascular permeability, and collagen degradation. ${ }^{17}$ In the same study, $\mathrm{PGE}_{2}$ was also positively related to TNF- $\alpha$ and IL-1 $\beta .^{17}$

IL-1 has the main function of mediating the host's inflammatory response to infections and to other stimuli, similarly to the effects of TNF. It acts on endothelial cells by inducing the expression of surface molecules that mediate leukocyte adhesion. Macrophages are the main source of IL-1 production, with neutrophils and endothelial cells involved in their production. There are two forms of IL-1, alpha $(\alpha)$ and beta $(\beta)$, the latter of which is the most commonly found in the human circulatory system. ${ }^{155}$ IL-1 $\alpha$ plays a critical role in protecting the body from external invaders such as bacteria and viruses, and it is also involved in bone resorption. ${ }^{156}$ IL-1 $\beta$ has been correlated with clinical signs/symptoms and with greater bone resorption. ${ }^{157}$

In addition to mediating the production of potent inflammatory molecules, such as prostaglandins, leukotrienes, platelet-activating factor, and cytokines, and positively regulating endothelial cell adhesion molecules, IL-1 affects several processes of the innate immune response. It has been implicated as a central mediator during bone and tissue destruction processes. ${ }^{158,159}$ 
IL-6 is a cytokine that mediates the host's response to infection and has been observed in exudates (EX) associated with endodontic apical lesions. ${ }^{160}$ In addition, IL-6 was positively correlated with the area of the radiographic lesion in the study by Martinho et al., ${ }^{17}$ thus confirming its role in bone resorption in chronic inflammatory periodontitis. However, the same study demonstrated that $\mathrm{PGE}_{2}$ and IL- 6 together were negatively correlated with the size of the radiographic lesion, confirming that the relationship between these cytokines is complex and difficult to establish in many respects. ${ }^{17} \mathrm{IL}-6$ has potent proinflammatory effects at local and systemic levels, including the acute-phase inflammatory response, in which C-reactive protein (CRP) can be detected in response to IL-6 action. ${ }^{160}$ Although IL-6 is detected in all analyzed samples of root canals, whether healthy or with apical periodontitis, in the latter cases its expression is significantly increased. ${ }^{160}$ IL-6 expression is induced by IL-1 $\beta$ and TNF- $\alpha$ during the early stages of inflammation, and all act synergistically, promoting the recruitment of PMNs and monocytes, shifting from acute to chronic inflammation, which induces activation of MMPs and stimulation of osteoclastogenesis and bone resorption. ${ }^{160}$

IL-8 is mainly produced by monocytes/macrophages and in smaller amounts by fibroblasts, endothelial cells, keratinocytes, melanocytes, hepatocytes, and chondrocytes. Its stimuli are usually IL- 1, TNF- $\alpha$, and IFN-g. IL-8 can be inhibited by corticosteroids and cyclosporine A. It is a chemokine, thus increasing chemokinesis and acting as a chemiotactic factor. The term 'chemokine' comes from the contraction of 'chemotactic cytokines'. Other chemokines include MIP-1a, MIP-1b, MCP, eotaxin, and RANTES. IL-8 provides potent migratory stimulus for the cells of the immune system, mainly neutrophils, also determining an increase in the expression of adhesion molecules by endothelial cells. It also activates PMNs, increasing oxidative metabolism. It antagonizes the production of IgE stimulated by IL-4, but it does not affect the production of other immunoglobulins. ${ }^{150}$

IL-10 is produced by monocytes, macrophages, and lymphocytes, ${ }^{161,162}$ originally identified for their ability to antagonize cellular immunity. ${ }^{163}$ Among its characteristics, immunosuppression is noteworthy, as it depresses the activation of mononuclear cells and prevents the production of mediators of inflammation. ${ }^{163,164} \mathrm{IL}-10$ inhibits antigen presentation in monocytes by negative regulation of MHC class $\mathrm{II}^{163}$ and the in vitro expression of costimulatory molecules. ${ }^{165}$ Its biological effects would be a consequence of its ability to inhibit many of the functions of activated macrophages, such as the production of IL-12 and TNF- $\alpha .{ }^{155}$

Although many of the cytokines involved in the immunoregulatory network were identified in apical periodontitis, the longitudinal expression of this network and its effects on proinflammatory cytokines still need to be further investigated.

\section{The role of matrix metalloproteinases}

Matrix metalloproteinases are members of an enzyme family that require a zinc ion in their active site for catalytic activity. MMPs are critical for maintaining tissue allostasis. MMPs are active at neutral $\mathrm{pH}$ and can therefore catalyze the normal turnover of extracellular matrix (ECM) macromolecules such as interstitial and basement membrane collagens, proteoglycans such as aggrecan, decorin, biglycan, fibromodulin, and versican, as well as accessory ECM proteins such as fibronectin. ${ }^{166}$

The degradation of the ECM by MMPs seems to be an important trigger for the progression of the inflammatory process. ${ }^{148,167}$

Proinflammatory cytokines, such as IL-1 $\beta$ and TNF$\alpha$, are able to stimulate, either directly or indirectly, the release of MMPs in the periapical/periodontal region, maintaining a persistent inflammatory process. ${ }^{30,168}$ MMPs are deeply involved in the pathogenesis of pulp, periodontal, and periapical tissue destruction. ${ }^{168}$

MMPs are commonly organized in groups, based partly on historical assessment of the substrate specificity of the MMP and partly on the cellular localization of the MMP. These groups are the collagenases [MMP 1 (interstitial collagenase), MMP 8 (neutrophil collagenase), MMP 13 (collagenase 3), MMP18 (collagenase 4)], the gelatinases [MMP 2 (gelatinase A), 9 (gelatinase B)], the stromelysins (MMP 3, 10, 11), membrane-type MMPs (MT-MMPs 14, 15, 16, 17, 23A, 23B, 24, 25), and other MMPs. ${ }^{169}$

MMP-2 (gelatinase A) and MMP-9 (gelatinase B) are of particular interest in endodontics, because there is 
evidence that these MMPs play an important role in the pathogenesis of pulp, periodontal, and periapical tissue destruction. ${ }^{170,171}$ They are responsible for the degradation of gelatin (denatured collagen) and type IV collagen, the major component of basement membranes. ${ }^{172}$

MMP-2 can also degrade collagens V, VII, and X, decorin, elastin, and fibronectin. ${ }^{172,173}$ Its collagenolytic activity is shown by its action on fibroblasts, the main constituent cells of connective tissue of the periodontal ligament, responsible for collagen production. ${ }^{30}$ Fibroblasts secrete MMP-2 when induced by endodontic content in primary endodontic infections, and this process contributes to the progression of periapical inflammation and tissue destruction. ${ }^{30}$

It has been reported that the expression of MMP-9 in inflamed pulps has shown higher levels than those recorded in clinically healthy pulps. ${ }^{167}$ MMP-9 was detected in endothelial cells, osteoblasts, fibroblasts, and inflammatory cells, and could be released during the inflammatory reaction induced directly by bacteria or indirectly by proinflammatory cytokines, evidencing the role of MMPs in the pathogenesis of inflammation, ${ }^{27}$ where its synthesis is controlled by proinflammatory cytokines. ${ }^{167}$

Ahmed et al. ${ }^{167}$ showed a correlation between gram-negative bacteria and MMP-9 hyperactivity in symptomatic periapical lesions. MMPs also act in the processes of bone resorption and destruction of periapical tissues, promoting direct degradation of the ECM, exhibiting a correlation between the concentration of gram-negative bacteria and MMP-9 expression in symptomatic periapical lesions. ${ }^{167}$

The destruction of the periodontal ligament is initiated by the degradation of extracellular membrane and serine proteases. ${ }^{174}$ Connective tissue destruction is essentially controlled by MMPs, which contributes to the destruction of gingival tissue and alveolar bone surrounding the teeth. ${ }^{23} \mathrm{MMP}$ activity requires a balance with the intrinsic inhibitors known as tissue inhibitors of MMPs (TIMPs), ${ }^{27,175}$ because an excessive production of MMPs leads to accelerated matrix degradation and tissue destruction, which is associated with pathological conditions such as periodontitis and apical periodontitis. ${ }^{168,176}$

Specific Quantikine ELISA kits (R\&D Systems, Minneapolis, MD, USA) have been used for measurement of both cytokines (IL-1 $\alpha$, IL-1 $\beta$, TNF- $\alpha$, and $\mathrm{PGE}_{2}$ ) and MMPs (MMP-2, MMP-3, MMP-8, MMP9, and MMP-13). Cytokines and MMPs are measured indirectly after stimulation of host cells (macrophages and fibroblasts) with infectious contents, ${ }^{17,29,30}$ or directly from samples of the periapical region. . $7,140^{2}$

Regardless of the method used, the data obtained in the studies mentioned above reveal that MMPs are involved in apical periodontitis because they interact with complex networks, which include cytokines, in the development of clinical features and severity of bone destruction.

\section{Association of microorganisms with endodontic clinical features}

The microbiota of infected root canals consists of a complex polymicrobial population. In such heterogeneous community, interactions among several microbial species may play a significant role in the balance between individual microorganisms. Combinations of bacteria are more potent at inducing pathological state in the host (e.g., apical periodontitis) than are single strains. Moreover, complex interactions of species result in characteristic clinical pictures that cannot be achieved by individual species alone. ${ }^{6}$

Gram-negative species, such as Fusobacterium, Prevotella, and Porphyromonas, are likely to have some clinical significance due to the presence of endotoxin. LPS has many biological activities, including fever induction, adjuvant activity, Schwartzman reaction, cytotoxicity, blood clotting, fibrinolysis, and production of bradykinin, which is a potent pain mediator. ${ }^{4-7,130}$ However, the cell walls of gram-positive bacteria such as Peptostreptococcus and Eubacterium spp. can also produce inflammatory reactions due to the presence of peptidoglycans and LTA. They enhance the pathogenicity of "black-pigmented Bacteroides" and are also related to acute symptoms and destruction of periapical tissues. The combination of P. micros and Prevotella spp. was associated with clinical features such as pain and swelling.4.7 One explanation for the synergy between these species is the known enhancement of the endotoxin effect by gram-positive superantigens. ${ }^{7}$ Superantigens interact with antigen-presenting cells (APCs), such as macrophages and $\mathrm{T}$ cells, inducing cell proliferation 
and massive cytokine production, which leads to clinical symptomatology. ${ }^{177}$

A long-held desire in endodontic microbiology has been to find a single or at least a group of bacterial species that is responsible for acute symptoms. ${ }^{32,78}$ However, while several bacterial species seem to be more prevalent when associated with pain, the very same species have also been encountered in asymptomatic cases. The possibility exists that some of these species really play a role in making the bacterial mixed community more virulent. Several other factors can be regarded as influential to the development of symptoms, including differences in virulence among clonal types of the same species, bacterial interactions in the multispecies community, resulting in collective pathogenicity, total and specific bacterial counts, and host-related factors. ${ }^{32}$

Endodontic symptomatology includes history of pain, spontaneous pain, pain on palpation (POP), and tenderness to percussion (TTP). Clinical signs mean presence of sinus swelling in periodontal tissues, presence of apical periodontitis, status of the root canal such as dry canal, and presence of clear, hemorrhagic, or purulent exudate.

Several works using the strict anaerobic culture technique reported an association between specific bacteria and endodontic signs and symptoms. ${ }^{4-7,72-74,85,178-181}$

Nowadays, with the advance of molecular microbiology, thanks to which more than 500 species or phylotypes have been detected in root canals, it seems even harder to associate a species or group of species with clinical symptoms and signs. Nevertheless, the bacterial community profiles associated with teeth with symptomatic apical periodontitis are significantly different from asymptomatic lesions. The same has been observed for teeth with primary versus posttreatment apical periodontitis. ${ }^{32}$

\section{Association of LPS with clinical features}

Anaerobic gram-negative bacteria have been frequently isolated from root canals of endodontically involved teeth; consequently, their endotoxins may affect the periapical tissues and exert a role in the pathogenesis of inflammatory lesions of pulpal origin. ${ }^{15}$
Since the work by Schein and Schilder, ${ }^{13}$ the relationship between endotoxin levels and presence of endodontic clinical signs and symptoms has been investigated. These authors found a significant correlation between endotoxin levels and presence of exudate and radiolucent areas. ${ }^{13}$

Horiba et al. ${ }^{31}$ showed that teeth with clinical symptoms contained higher levels of endotoxin than those that were asymptomatic. Jacinto et al. ${ }^{15}$ reported a positive association between endotoxin and symptomatic cases (e.g., spontaneous pain, TTP, POP, swelling, and purulent exudate), which exhibited higher levels of endotoxin than asymptomatic cases. A negative association was reported between the endotoxin present in the root canals and asymptomatic teeth. ${ }^{15}$

Martinho and Gomes ${ }^{16}$ found a positive correlation between LPS and TTP in primary infected root canals. Higher levels of endotoxin were found in teeth with clinical symptomatology.

Martinho et al. ${ }^{11}$ reported that larger areas of bone destruction, identified by the size of the radiolucent area, were related to higher levels of endotoxin. Additionally, a correlation was found between levels of endotoxins and the number of gram-negative bacterial species. Moreover, higher levels of endotoxin were detected in teeth with exudate. ${ }^{12}$

Endo et al., ${ }^{19}$ after investigating endotoxin levels in teeth with post-treatment apical periodontitis, reported that higher levels of endotoxin are related to a larger radiolucent area (> $5 \mathrm{~mm}$ ).

Gomes et al. ${ }^{20}$ compared root canal samples collected from primary and secondary infections with median levels of endotoxins found in primary and secondary endodontic infections with apical periodontitis by correlating LPS contents with clinical/ radiographic findings. Endotoxins were detected in $100 \%$ of the values of $7.49 \mathrm{EU} / \mathrm{mL}$ and $3.96 \mathrm{EU} / \mathrm{mL}$, respectively $(p<.05)$. The median value of endotoxins found in the presence of clinical symptoms was significantly higher than in asymptomatic teeth with primary infections $(\mathrm{p}<.05)$. A positive correlation was found between endotoxin contents and a larger radiolucent area $(>3 \mathrm{~mm})(\mathrm{p}<.05) .{ }^{20}$

Martinho et al., ${ }^{18}$ in their systematic review and meta-analysis, evaluated the relationship between endotoxin levels and presence of clinical signs/ 
symptoms and radiographic features in patients with endodontic infection. Among the 385 articles identified in their initial search, 30 were included for full-text appraisal and only eight studies ${ }^{11-13,15,16,19,20,31}$ met the inclusion criteria for the systematic review.

The meta-analysis revealed that individuals with teeth with TTP $\left(p=0.04 ; I^{2} 57 \%\right)^{11-13,15,16,19,20}$ and previous episode of pain (PEP, $\left.\mathrm{p}=0.001 ; \mathrm{I}^{2} 81 \%\right)^{15,16,31}$ had higher levels of endotoxin than their counterparts. These correlations are consistent with the hypothesis that LPS in clinical infections is related to the production of pain and mechanical allodynia. ${ }^{18}$

Size of radiographic lesion $>2 \mathrm{~mm}$ (SRL, $\mathrm{p}=$ 0.02; $\mathrm{I}^{2} 68 \%$ ) was also associated with higher levels

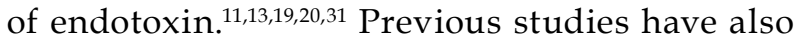
demonstrated this association, where the endotoxin content of teeth with radiolucent areas is five times as great as that of teeth without them. ${ }^{183}$

Presence of root canal exudation $\left(\mathrm{p}=0.0007 ; \mathrm{I}^{2} 0 \%\right)$ was associated with higher levels of endotoxins, ${ }^{11,12,31}$ indicating acute inflammation in a periapical lesion. Overall, the meta-analysis provided strong evidence that endotoxin is related to the presence of clinical signs/symptoms and radiographic features in patients with endodontic infection. ${ }^{18}$

It is important to highlight that not only the levels of endotoxin are implicated in the presence/development of symptoms and severity of bone destruction, but also the bacterial community involved in the infection, its interplay (synergism/antagonism), and consequently, the type of bacterial LPS and its lipid A structure. ${ }^{18}$

Since a more complex gram-negative bacterial community is associated with a primary endodontic infection, it is clear that higher levels of endotoxins will be present in these teeth compared with teeth with secondary infections. ${ }^{20}$ However, both situations have been associated with the relation between endotoxin levels and bone destruction in periapical tissues as well as with the development of clinical features. Thus, it is important to correlate endotoxin levels with immune stimuli by the expression of inflammatory mediators.

\section{Association of LPS with cytokines}

LPS is considered the major etiologic component responsible for pathophysiology of inflammation and post-infectious sequelae. It is able to potently activate monocytes/macrophages, causing rapid release of cytokines in periradicular sites related to tissue destruction. ${ }^{21,22}$

Gram-negative species tend to induce a higher ratio of cytokines, particularly TNF- $\alpha$. However, interleukins such as IL-1 $\beta$, IL-6, IL-8, and IL-10 are also increased during the course of endodontic infection. Chemokines such as CXCL2 and CXCL10 are also detected in endodontic infections. Chemokines activate inflammatory cells and also influence angiogenesis. ${ }^{144}$

Positive correlations have been established between the number of gram-negative bacteria, endotoxin contents, and the levels of TNF- $\alpha$, IL- $1 \beta$, and PGE 2 found in primarily infected root canals. ${ }^{11,12,144}$

Although LPS is known to induce cytokine production, the amount of cytokines can be lowered to control inflammation by providing immune cells with 'LPS tolerance.' This can be done by exposing immune cells to low doses of LPS. The ability to develop tolerance is also better in young than in older adults. ${ }^{144}$

Cytokines/MMPs and clinical symptomatology

The virulence factors present in gram-negative(LPS) and in gram-positive bacteria (LTA) are responsible for stimulating host cells to express various cytokines, most of which are harmful to the host organism. Specific functions are assigned to each cytokine and the effects of their interactions are implicated in the development of clinical signs and symptoms, as well as in the mechanisms of bone resorption exhibited by apical periodontitis.

The study of Martinho et al. ${ }^{26}$ showed several correlations between clinical symptomatology and cytokine expression. The presence of POP has been positively associated with TNF- $\alpha$ and IFN- $\gamma$, whereas higher levels of IL-4 and IL-13 decreased the chances of POP. The chance of having TTP is increased in the presence of higher levels of TNF- $\alpha$ and IFN- $\gamma$, whereas elevated levels of IL-4, IL-5, and IL-13 were considered a protective factor. Larger size of bone destruction $(>3 \mathrm{~mm}$ ) was positively associated with TNF- $\alpha$ and negatively associated with higher levels of IL-4.

Due to the large number of studies that have linked the role of proinflammatory cytokines to the pathogenesis and progression of periapical/ 
periodontal disease, the possibility of interventions with the manipulation of anti-inflammatory cytokines as adjuvant therapies in patients with these diseases indicates a new era in endodontic regeneration.

An important interplay has been established between cytokines and other inflammatory mediators, including MMPs. It has been reported that proinflammatory cytokines such as IL-1 $\alpha$, IL-1- $\beta$, IL-6, and TNF $\alpha$ can enhance MMP expression and production in human periodontal ligament cells. ${ }^{184}$ MMPs are involved in the breakdown of the ECM and in the processing of a variety of biological molecules. ${ }^{185}$ They play an important role in many physiological and pathological processes..$^{154,185-187}$ Herrera et al. ${ }^{30}$ showed that root canal contents from primary endodontic infections have gelatinolytic activity for MMP-2. The authors also reported that endotoxin levels achieved after chemomechanical preparation (CMP) do not have antigenicity against fibroblasts for MMP-2 and MMP-9 expression. ${ }^{30}$

Table 4 shows the main cytokines and MMPs reported in previous studies and their involvement in the immune response/clinical symptomatology of apical periodontitis.

Tissue breakdown in apical periodontitis is the result of the imbalance in the interplay between the local host immune response and different inflammatory mediators stimulated by infection of the root canal system. Clinicians should be guided by endodontic protocols that allow the reduction of higher levels of endodontic infectious contents and, consequently, the reduction of complex interplay mechanisms. This, in turn, will lead to the restoration of the balance between host immune response and inflammatory mediators in the periapical region.

\section{Treatment of the endodontic infection}

The objective of endodontic treatment is the removal of pain of pulp and periapical origin and the prevention and treatment of pulpal and periapical diseases. To achieve that, principles of infection control are of great importance. These principles should be adopted before the beginning of the endodontic treatment, with antisepsis of the operative field and the use of instruments and sterile substances, followed by crown decontamination and CMP, where the mechanical action of the instruments throughout the root canal, combined with the use of auxiliary chemical substances and efficient irrigation, will reduce the levels of microorganisms and their virulence factors in the root canal system. ${ }^{32}$

Technological advances in instrumentation have brought significant improvements in the ability to shape the root canals; however, recent micro-CT studies have revealed that around 10 to $50 \%$ of the root canal area remains intact after the action

Table 4. Main cytokines and MMPs reported in previous studies and their involvement in the immune response / clinical symptomatology of apical periodontitis.

\begin{tabular}{|c|c|c|c|c|c|c|}
\hline \multirow[t]{2}{*}{ Author } & \multirow{2}{*}{ Biomarker } & \multirow{2}{*}{ Primary function } & \multicolumn{4}{|c|}{$\begin{array}{c}\text { Significant association with } \\
\text { clinical features }\end{array}$} \\
\hline & & & POP & TTP & EX & $>\mathrm{SRL}$ \\
\hline $\begin{array}{l}\text { Martinho et al. }(2010 a),{ }^{11}(2014),{ }^{25} \\
\text { Cardoso et al. }(2016)^{132}\end{array}$ & IL-1 $\beta$ & Expression of adhesion factors, diapedesis, fever & + & + & + & + \\
\hline Martinho et al. $(2012)^{17}$ & IL-6 & Acute phase response, fever & & & & + \\
\hline $\begin{array}{l}\text { Martinho et al. }(2010 a),,^{11}(2012),{ }^{17}(2014),,^{25} \\
\text { Cardoso et al. }(2016)^{132}\end{array}$ & TNF- $\alpha$ & Cardinal signs of inflammation, fever & + & + & + & + \\
\hline Martinho et al. $(2011)^{12}$ & PGE2 & Vasodilatation, Collagen degradation & & + & + & \\
\hline Shin et al. (2002), ${ }^{170}$ Martinho et al. $(2016 a)^{27}$ & MMP-1 & Collagen degradation & & & & + \\
\hline Martinho et al. $(2016 a)^{27}$ & MMP-2 & Collagen degradation & & + & & + \\
\hline Martinho et al. $(2016 a)^{27}$ & MMP-9 & Collagen degradation & + & & & + \\
\hline
\end{tabular}

POP: Pain on palpation; TTP: Tenderness to percussion; EX: Exudation; > SRL: Higher size of radiographic lesion. 
of the instruments. ${ }^{188-190}$ These areas may harbor bacterial biofilm that remains unchanged after $\mathrm{CMP}$, compromising treatment outcome. Moreover, with the advent of the rotary instrumentation system, instrumentation time has been decreased as well as the contact time of the auxiliary chemical with the substrates present in the root canals. This emphasizes the need for efficient irrigation with effective antimicrobial substances.

Several substances have been recommended for use during CMP, including mainly sodium hypochlorite $(\mathrm{NaOCl})$, chlorhexidine $(\mathrm{CHX})$, and $17 \%$ ethylenediaminetetraacetic acid (EDTA). ${ }^{191} \mathrm{NaOCl}$ is the main endodontic irrigant used, because of its antibacterial properties and ability to dissolve organic tissues. ${ }^{192} \mathrm{CHX}$, usually at $2 \%$ and in a gelbased format, has been proposed as an alternative to $\mathrm{NaOCl}$ because of its antimicrobial activity against gram-negative and gram-positive bacteria, ${ }^{191}$ substantivity, ${ }^{193,194}$ and lower cytotoxicity. ${ }^{195}$ EDTA is widely used in clinical practice since it removes the contaminated smear layer and debris formed during $\mathrm{CMP}$, opening the dentinal tubules to receive an intracanal medication (ICM) or an endodontic sealer. ${ }^{196}$ Despite the consecrated properties of each of these irrigants, none of them is sufficiently capable of thoroughly disinfecting the root canal system. Thus, CMP should not be focused only on the mechanical approach and on passive irrigation.

Different systems of mechanical activation of irrigants to improve endodontic disinfection have been reported in the literature, ${ }^{197,198}$ including manual dynamic activation with gutta-percha cones, ${ }^{199}$ endodontic instruments or special brushes, ${ }^{197}$ vibrating systems activated by sonic energy, ${ }^{199,200}$ use of ultrasonic ${ }^{201}$ or laser energy ${ }^{202}$ to activate the irrigants, and apical negative-pressure irrigation systems. ${ }^{203}$ Protocols designed to improve intracanal decontamination by a specific chemical action include ozone ${ }^{204}$ and direct laser/light-activated disinfection..$^{205-207}$

From a semantic point of view, and given that chemical substances used as irrigants are already 'active', the term 'activation' of the irrigants does not describe the process properly. Similarly, 'passive' ultrasonic irrigation (PUI) is in fact active; however, when it was first introduced, the term 'passive' was related to the 'noncutting' action of the ultrasonically activated file. ${ }^{209}$

PUI has been used to enhance the chemical action of endodontic irrigants, whether antimicrobial activity $(\mathrm{NaOCl} / \mathrm{CHX})$, tissue-dissolving activity $(\mathrm{NaOCl})$, or chelating activity (EDTA). After CMP, the enlarged canal allows not only a better flow and backflow of the irrigants, but also the free vibration of the ultrasonic tip, ${ }^{139}$ particularly in the apical third, where it is almost impossible to achieve a complete renewal of the irrigant with conventional irrigation.

Ultrasonic activation is reported to be more effective than needle irrigation in removing bacteria from root canals. ${ }^{139,209}$ However, in relation to the reduction of endotoxin levels, its action is controversial, as Herrera et $\mathrm{al}_{1}{ }^{139}$ reported reduction, while Nakamura et al. ${ }^{209}$ did not. Nevertheless, the use of ultrasound allows a more intense flow of EDTA against root canal walls and into areas that are not reachable by root canal instrumentation and conventional irrigation, acting on remaining endotoxins. ${ }^{139}$ Additionally, this protocol could improve the outcome of endodontic treatment because EDTA has the capacity to rise the rate of LPSlipoprotein binding by increasing the disaggregation of the endotoxin..$^{210}$ Lipoprotein-bound LPS does not stimulate host immune cells and is less active than free LPS to induce proinflammatory cytokine expression. ${ }^{211}$

In order to complement the action of CMP, the use of an efficient ICM for an adequate time period is indicated, particularly in those cases with persistent exudate, TTP, and or POP. Other indications not related to infection are the presence of teeth with an open apex, insufficient time to conclude treatment, fatigue of the patient or operator, among others. ${ }^{32}$

Calcium hydroxide-based ICMs have been widely used as an antimicrobial strategy in the management of infected root canal systems. Nevertheless, there is no evidence to suggest that completion of root canal treatment in a single visit or over two or more visits, with or without ICM, makes any difference in term of effectiveness or complications. ${ }^{212}$ The antimicrobial effects of calcium hydroxide are probably due to protein denaturation and damage to DNA and cytoplasmic membranes, ${ }^{213}$ while its detoxifying activity occurs by hydrolysis of lipid A in fatty sugars and nontoxic amino acids. ${ }^{54,114}$. 
Even after ICM, microorganisms and their by-products may still remain in the root canal. However, their presence does not necessarily means treatment failure, unless there is a pathway of communication linking the root canal to the periapical/periodontal tissues. The threshold levels of endotoxin present in the root canal to induce damage to periapical tissues still have to be determined; however, evidence shows that minimal amounts of endotoxins can induce or maintain an inflammatory process.

The treatment of teeth with suspected apical biofilm after conventional endodontic treatment has been attempted consists of the surgical removal of the apical portion of the tooth, followed by retrograde instrumentation and obturation. At present, there is no auxiliary chemical or ICM capable of destroying the apical biofilm or disorganizing its structure.

It is evident that the integration of new technologies and materials into endodontic therapy can improve the clinical outcome. Nonetheless, after root canal filling, a well-adapted definitive coronal restoration should be placed to prevent coronal microleakage, root canal reinfection, and the risk of root fracture. ${ }^{32}$

\section{Final remarks}

Although the polymicrobial etiology of apical periodontitis has been described, the role of individual microbial species in the development, progression, and dissemination of periradicular diseases has not yet been well established. The prevalence of several microbial species has been highlighted in endodontic infections; however, the pathogenic process of apical periodontitis is also related to the number and virulence of the microorganisms and to host's resistance. The virulence of the microorganisms may be affected by the synergistic relationships between the bacteria found in the root canal system.

The association between certain anaerobic species and endodontic signs and symptoms, such as the presence of spontaneous pain, TTP, POP, swelling, and purulent exudate, is directly related to the cytotoxicity of each species. Because of the high toxicity of gramnegative bacterial species and their main virulence factor (endotoxin), stimulating immune cells to release different inflammatory mediators, endodontic therapy should not only rely on reducing/eliminating planktonic and sessile microorganisms and substrates, ${ }^{214}$ but also on reducing endotoxins to levels that are compatible with periradicular tissue healing. $32,64,136$

The residual endotoxins found after CMP, if access to periradicular tissues is allowed, would modulate host immune responses by the expression of different cytokines and MMPs. ${ }^{30,54}$ Moreover, it has been shown that an elevated inflammatory state caused by metabolic disorders can impact the clinical outcome of periapical lesions and interfere with wound healing after endodontic treatment. Immunoregulatory cytokines produced by various cell types, including immune cells and adipose tissue, play an important role in this interrelationship. ${ }^{38}$

In conclusion, research is necessary to better understand microbial communities and the complex networks activated by the infectious/inflammatory content of an infected root canal, which will act in the development of clinical features and influence the severity of bone destruction. Moreover, improvement in endodontic instruments, instrumentation systems, irrigants, and ICM, along with the development of novel therapeutic approaches, are crucial for more effective procedures for treating infected root canals.

\section{Acknowledgments}

We would like to thank all members and graduate students at the Endodontics Division of the Piracicaba Dental School, State University of Campinas, UNICAMP, Brazil, for providing part of the material and figures used in this review. We would also like to thank Maicon Ricardo Zieberg and Ana Regina de Oliveira Polay for their technical support, and Lonza for the equipment. We thank Dr. Jefferson J. C. Marion, from the Federal University of Mato Grosso do Sul (UFMS), for contributing with Figure 1A. Finally, we would like to thank the following Brazilian research grant agencies for their support: São Paulo Research Foundation (FAPESP) process no. 2015/23479-5; Brazilian Coordination for the Improvement of Higher Education and Graduate Training Personnel (CAPES); National Council for Scientific and Technological Development (CNPq) process no. 308162/2014-5; University of Campinas and the Teaching and Extension Support Fund (FAEPEX) process no. 2036/17, agreement 519.292. 
Etiologic role of root canal infection in apical periodontitis and its relationship with clinical symptomatology

\section{References}

1. Nair PN. Pathogenesis of apical periodontitis and the causes of endodontic failures. Crit Rev Oral Biol Med. 2004 Nov; 15(6):348-81. https://doi.org/10.1177/154411130401500604

2. Nair PN. Apical periodontitis: a dynamic encounter between root canal infection and host response. Periodontol 2000. 1997 Feb;13(1):121-48. https://doi.org/10.1111/j.1600-0757.1997.tb00098.x

3. Fabricius L, Dahlén G, Holm SE, Möller AJ. Influence of combinations of oral bacteria on periapical tissues of monkeys. Scand J Dent Res. 1982 Jun;90(3):200-6. https://doi.org/10.1111/j.1600-0722.1982.tb00728.x

4. Gomes BP, Drucker DB, Lilley JD. Associations of specific bacteria with some endodontic signs and symptoms. Int Endod J. 1994 Nov;27(6):291-8. https://doi.org/10.1111/j.1365-2591.1994.tb00271.x

5. Gomes BP, Lilley JD, Drucker DB. Associations of endodontic symptoms and signs with particular combinations of specific bacteria. Int Endod J. 1996a Mar;29(2):69-75. https://doi.org/10.1111/j.1365-2591.1996.tb01164.x

6. Gomes BP, Lilley JD, Drucker DB. Clinical significance of dental root canal microflora. J Dent. 1996b Jan-Mar;24(1-2):47-55. https://doi.org/10.1016/0300-5712(95)00042-9

7. Gomes BP, Pinheiro ET, Gadê-Neto CR, Sousa EL, Ferraz CC, Zaia AA, et al. Microbiological examination of infected dental root canals. Oral Microbiol Immunol. 2004 Apr;19(2):71-6. https://doi.org/10.1046/j.0902-0055.2003.00116.x

8. Gomes BP, Berber VB, Kokaras AS, Chen T, Paster $B J$. Microbiomes of endodontic-periodontal lesions before and after chemomechanical preparation. J Endod. 2015 Dec;41(12):1975-84. https://doi.org/10.1016/i.joen.2015.08.022

9. Siqueira Junior JF, Rôças IN. Exploiting molecular methods to explore endodontic infections: Part 2-Redefining the endodontic microbiota. J Endod. 2005a Jul;31(7):488-98. https://doi.org/10.1097/01.don.0000157990.86638.49

10. Siqueira Junior JF, Rôças IN. Diversity of endodontic microbiota revisited. J Dent Res. 2009 Nov;88(11):969-81. https://doi.org/10.1177/0022034509346549

11. Martinho FC, Chiesa WM, Leite FR, Cirelli JA, Gomes BP. Antigenic activity of bacterial endodontic contents from primary root canal infection with periapical lesions against macrophage in the release of interleukin-1 beta and tumor necrosis factor alpha. J Endod. 2010a Sep;36(9):1467-74. https://doi.org/10.1016/i.joen.2010.06.012

12. Martinho FC, Chiesa WM, Leite FR, Cirelli JA, Gomes BP. Antigenicity of primary endodontic infection against macrophages by the levels of PGE(2) production. J Endod. 2011a May;37(5):602-7. https://doi.org/10.1016/i.joen.2010.12.005
13. Schein B, Schilder H. Endotoxin content in endodontically involved teeth. J Endod. 1975 Jan;1(1):19-21. https://doi. org/10.1016/S0099-2399(75)80244-5 PMID:1061764

14. Horiba N, Maekawa Y, Yamauchi Y, Ito M, Matsumoto T, Nakamura H. Complement activation by lipopolysaccharides purified from root canals. Oral Surg Oral Med Oral Pathol. 1992;74(5):648-51. https://doi.org/10.1016/0030-4220(92)90360-3

15. Jacinto RC, Gomes BP, Shah HN, Ferraz CC, Zaia AA, SouzaFilho FJ. Quantification of endotoxins in necrotic root canals from symptomatic and asymptomatic teeth. J Med Microbiol. 2005 Aug;54(Pt 8):777-83. https://doi.org/10.1099/jmm.0.45976-0

16. Martinho FC, Gomes BP. Quantification of endotoxins and cultivable bacteria in root canal infection before and after chemomechanical preparation with 2.5\% sodium hypochlorite. J Endod. 2008 Mar;34(3):268-72. https://doi.org/10.1016/i.joen.2007.11.015

17. Martinho FC, Chiesa WM, Leite FR, Cirelli JA, Gomes BP. Correlation between clinical/radiographic features and inflammatory cytokine networks produced by macrophages stimulated with endodontic content. J Endod. 2012 Jun;38(6):740-5. https://doi.org/10.1016/i.joen.2012.02.021

18. Martinho FC, de Rabello DG, Ferreira LL, Nascimento GG. Participation of endotoxin in root canal infections: A systematic review and meta-analysis. Eur J Dent. 2017 JulSep;11(3):398-406. https://doi.org/10.4103/ejd.ejd_84_17

19. Endo MS, Martinho FC, Zaia AA, Ferraz CC, Almeida JF, Gomes BP. Quantification of cultivable bacteria and endotoxin in post-treatment apical periodontitis before and after chemo-mechanical preparation. Eur J Clin Microbiol Infect Dis. 2012 Oct;31(10):2575-83. https://doi.org/10.1007/s10096-012-1598-6

20. Gomes BP, Endo MS, Martinho FC. Comparison of endotoxin levels found in primary and secondary endodontic infections. J Endod. 2012 Aug;38(8):1082-6. https://doi.org/10.1016/i.joen.2012.04.021

21. Kayaoglu G, Ørstavik D. Virulence factors of Enterococcus faecalis: relationship to endodontic disease. Crit Rev Oral Biol Med. 2004 Sep;15(5):308-20. https://doi.org/10.1177/154411130401500506

22. Barbosa-Ribeiro M, De-Jesus-Soares A, Zaia AA, Ferraz CC, Almeida JF, Gomes BP. Quantification of lipoteichoic acid contents and cultivable bacteria at the different phases of the endodontic retreatment. J Endod. 2016 Apr;42(4):552-6. https://doi.org/10.1016/i.joen.2016.01.002

23. Sorsa T, Tiäderhane L, Konttinen YT, Lauhio A, Salo T, Lee $\mathrm{HM}$, et al. Matrix metalloproteinases: contribution to pathogenesis, diagnosis and treatment of periodontal inflammation. Ann Med. 2006;38(5):306-21. https://doi.org/10.1080/07853890600800103 
24. Kawashima N, Stashenko P. Expression of boneresorptive and regulatory cytokines in murine periapical inflammation. Arch Oral Biol. 1999 Jan;44(1):55-66. https://doi.org/10.1016/S0003-9969(98)00094-6

25. Martinho FC, Leite FR, Nascimento GG, Cirelli JA, Gomes BP. Clinical investigation of bacterial species and endotoxin in endodontic infection and evaluation of root canal content activity against macrophages by cytokine production. Clin Oral Investig. 2014 Dec;18(9):2095-102. https://doi.org/10.1007/s00784-014-1198-1

26. Martinho FC, Nascimento GG, Leite FR, Gomes AP, Freitas $L F$, Camões IC. Clinical influence of different intracanal medications on Th1-type and Th2-type cytokine responses in apical periodontitis. J Endod. 2015 Feb;41(2):169-75. https://doi.org/10.1016/i.joen.2014.09.028

27. Martinho FC, Teixeira FF, Cardoso FG, Ferreira NS, Nascimento GG, Carvalho CA, et al. Clinical investigation of matrix metalloproteinases, tissue inhibitors of matrix metalloproteinases, and matrix metalloproteinase/tissue inhibitors of matrix metalloproteinase complexes and their networks in apical periodontitis. J Endod. 2016a Jul;42(7):1082-8. https://doi.org/10.1016/i.joen.2016.04.001

28. Sousa EL, Martinho FC, Leite FR, Nascimento GG, Gomes BP. Macrophage cell activation with acute apical abscess contents determined by interleukin-1 Beta and tumor necrosis factor alpha production. J Endod. 2014a Nov;40(11):1752-7. https://doi.org/10.1016/j.joen.2014.06.019

29. Marinho AC, Martinho FC, Leite FR, Nascimento GG, Gomes BP. Proinflammatory activity of primarily infected endodontic content against macrophages after different phases of the root canal therapy. J Endod. 2015 Jun;41(6):817-23. https://doi.org/10.1016/i.joen.2015.01.017

30. Herrera DR, Silva EJ, Santos CC, Zaia AA, Ferraz CC, Almeida $\mathrm{JF}$, et al. Root canal content from primary endodontic infection and upregulation of gelatinases in fibroblast cells. Int Endod J. 2015 Dec;48(12):1168-74. https://doi.org/10.1111/iej.12421

31. Horiba N, Maekawa Y, Abe Y, Ito M, Matsumoto T, Nakamura $\mathrm{H}$. Correlations between endotoxin and clinical symptoms or radiolucent areas in infected root canals. Oral Surg Oral Med Oral Pathol. 1991 Apr;71(4):492-5. https://doi.org/10.1016/0030-4220(91)90438-1

32. Gomes BP. R?? as IN, Siqueira Junior JF. Endodontic infections and therapeutical approaches. In: Lamont RJ, Hajishengallis GN, Jenkinson HF, Koo H, editors. Oral Microbiology and Immunology. 3rd ed. Washington (DC): ASM Press; [in press].

33. Aas JA, Paster BJ, Stokes LN, Olsen I, Dewhirst FE. Defining the normal bacterial flora of the oral cavity. J Clin Microbiol. 2005 Nov;43(11):5721-32. https://doi.org/10.1128/JCM.43.11.5721-5732.2005

34. Gomes BP. An investigation into the root canal microflora [thesis]. Manchester: University of Manchester; 1995.
35. Sundqvist G. Taxonomy, ecology, and pathogenicity of the root canal flora. Oral Surg Oral Med Oral Pathol. 1994 Oct;78(4):522-30. https://doi.org/10.1016/0030-4220(94)90047-7

36. Narayanan LL, Vaishnavi C. Endodontic microbiology. J Conserv Dent. 2010 Oct;13(4):233-9. https://doi.org/10.4103/0972-0707.73386

37. Smith AJ. Pulpal responses to caries and dental repair. Caries Res. 2002 Jul-Aug;36(4):223-32. https://doi.org/10.1159/000063930

38. Sasaki $H$, Hirai K, Martins CM, Furusho $H$, Battaglino R, Hashimoto K. Interrelationship between periapical lesion and systemic metabolic disorders. Curr Pharm Des. 2016;22(15):2204-15. https://doi.org/10.2174/1381612822666160216145107

39. Tronstad L, editor. Clinical endodontics: a textbook. 3rd rev.ed. Stuttgart, New York: Thieme; 2009. https://doi.org/10.1055/b-002-66245

40. Mattila KJ, Pussinen PJ, Paju S. Dental infections and cardiovascular diseases: a review. J Periodontol. 2005;76/11 Suppl):2085-8. https://doi.org/10.1902/jop.2005.76.11-S.2085

41. Flynn TR, Shanti RM, Levi MH, Adamo AK, Kraut RA, Trieger N. Severe odontogenic infections, part 1: prospective report. J Oral Maxillofac Surg. 2006 Jul;64(7):1093-103. https://doi.org/10.1016/i.joms.2006.03.015

42. Yamasaki M, Kumazawa M, Kohsaka T, Nakamura H, Kameyama Y. Pulpal and periapical tissue reactions after experimental pulpal exposure in rats. J Endod. 1994 Jan;20(1):13-7. https://doi.org/10.1016/S0099-2399(06)80020-8

43. Stashenko P, Wang CY, Riley E, Wu Y, Ostroff G, Niederman R. Reduction of infection-stimulated periapical bone resorption by the biological response modifier PGG glucan. J Dent Res. 1995 Jan;74(1):323-30. https://doi.org/10.1177/00220345950740010701

44. Hahn CL, Falkler WA Jr, Siegel MA. A study of T and B cells in pulpal pathosis. J Endod. 1989 Jan;15(1):20-6. https://doi.org/10.1016/S0099-2399(89)80093-7

45. Sundqvist $G$. Associations between microbial species in dental root canal infections. Oral Microbiol Immunol. 1992a Oct;7(5):257-62. https://doi.org/10.1111/j.1399-302X.1992.tb00584.x

46. Siqueira Junior JF, Rôças IN. Bacterial pathogenesis and mediators in apical periodontitis. Braz Dent J. 2007;18(4):267-80. https://doi.org/10.1590/S0103-64402007000400001

47. Sundqvist $G$. Ecology of the root canal flora. J Endod. 1992b Sep;18(9):427-30. https://doi.org/10.1016/S0099-2399(06)80842-3

48. Bergey DH, Holt JG. Bergey's Manual of determinative bacteriology. 9th ed. Baltimore: Williams \& Wilkins; 1994.

49. Dehus $O$, Hartung $T$, Hermann $C$. Endotoxin evaluation of eleven lipopolysaccharides by whole blood assay does not always correlate with Limulus amebocyte lysate assay. J Endotoxin Res. 2006;12(3):171-80. https://doi.org/10.1177/09680519060120030401 
- Etiologic role of root canal infection in apical periodontitis and its relationship with clinical symptomatology

50. Fouad AF. Endodontic microbiology. Ames; Wiley-Blackwell; 2009.

51. Westphal O. Bacterial endotoxins. Int Arch Allergy Appl Immunol. 1975;49(1-2):1-43. https://doi.org/10.1159/000231374

52. Rietschel ET, Brade H. Bacterial endotoxins. Sci Am. 1992 Aug;267(2):54-61. https://doi.org/10.1038/scientificamerican0892-54

53. Darveau RP, Pham TT, Lemley K, Reife RA, Bainbridge BW, Coats $S R$ et al. Porphyromonas gingivalis lipopolysaccharide contains multiple lipid A species that functionally interact with both toll-like receptors 2 and 4. Infect Immun. 2004 Sep;72(9):5041-51. https://doi.org/10.1128/IAI.72.9.5041-5051.2004

54. Marinho AC, To TT, Darveau RP, Gomes BP. Detection and function of lipopolysaccharide and its purified lipid $A$ after treatment with auxiliary chemical substances and calcium hydroxide dressings used in endodontic therapy. Int Endod J. https://doi.org/10.1111/IEJ.12920

55. Ginsburg I. Role of lipoteichoic acid in infection and inflammation. Lancet Infect Dis. 2002 Mar;2(3):171-9. https://doi.org/10.1016/S1473-3099(02)00226-8

56. Signoretto C, Lleò MM, Tafi MC, Canepari P. Cell wall chemical composition of Enterococcus faecalis in the viable but nonculturable state. Appl Environ Microbiol. 2000 May;66(5):1953-9. https://doi.org/10.1128/AEM.66.5.1953-1959.2000

57. Zhao L, Chen J, Cheng L, Wang X, Du J, Wang F et al. Effects of Enterococcus faecalis lipoteichoic acid on receptor activator of nuclear factor- $\mathrm{\kappa} B$ ligand and osteoprotegerin expression in periodontal ligament fibroblasts. Int Endod J. 2014 Feb;47(2):163-72. https://doi.org/10.1111/iej.12127

58. Bhakdi S, Klonisch T, Nuber P, Fischer W. Stimulation of monokine production by lipoteichoic acids. Infect Immun. 1991 Dec;59(12):4614-20.

59. Henderson B, Wilson M. Cytokine induction by bacteria: beyond lipopolysaccharide. Cytokine. 1996 Apr;8(4):269-82. https://doi.org/10.1006/cyto.1996.0036

60. Wang CY, Tani-Ishi N, Stashenko P. Bone resorption cytokine gene expression in developing rat periapical lesions. Oral Microbiol Immunol. 1997;12(2):65-71. https://doi.org/10.1111/j.1399-302X.1997.tb00619.x

61. Miller WD. The micro-organisms of the human mouth. Philadelphia: White Dental MFG Co.; 1890.

62. Vianna ME, Horz HP, Gomes BP, Conrads G. Microarrays complement culture methods for identification of bacteria in endodontic infections. Oral Microbiol Immunol. 2005 Aug;20(4):253-8. https://doi.org/10.1111/i.1399-302X.2005.00221.x

63. Siqueira Junior JF, Rôças IN. Exploiting molecular methods to explore endodontic infections: Part 1current molecular technologies for microbiological diagnosis. J Endod. 2005b Jun;31(6):411-23. https://doi.org/10.1097/01.don.0000157989.44949.26

64. Siqueira Junior JF, Rôças IN. Clinical implications and microbiology of bacterial persistence after treatment procedures. J Endod. 2008 Nov;34(11):1291-1301.e3. https://doi.org/10.1016/i.joen.2008.07.028
65. Margulies M, Egholm M, Altman WE, Attiya S, Bader JS, Bemben LA et al. Genome sequencing in microfabricated high-density picolitre reactors. Nature. 2005 Sep;437(7057):376-80. https://doi.org/10.1038/nature03959

66. Socransky SS, Smith C, Martin L, Paster BJ, Dewhirst FE, Levin AE. "Checkerboard" DNA-DNA hybridization. Biotechniques. 1994 Oct;17(4):788-92.

67. Sakamoto M, Rôças IN, Siqueira Junior JF, Benno Y. Molecular analysis of bacteria in asymptomatic and symptomatic endodontic infections. Oral Microbiol Immunol. 2006 Apr;21(2):112-22. https://doi.org/10.1111/j.1399-302X.2006.00270.x

68. Aw V. Discuss the role of microorganisms in the aetiology and pathogenesis of periapical disease. Aust Endod J. 2016 Aug;42(2):53-9. https://doi.org/10.1111/aej.12159

69. Zambon JJ, Haraszthy VI. The laboratory diagnosis of periodontal infections. Periodontol 2000. 1995 Feb;7(1):6982. https://doi.org/10.1111/j.1600-0757.1995.tb00037.x

70. Socransky SS, Haffajee AD, Cugini MA, Smith C, Kent RL Jr. Microbial complexes in subgingival plaque. J Clin Periodontol. 1998 Feb;25(2):134-44. https://doi.org/10.1111/j.1600-051X.1998.tb02419.x

71. Ozok AR, Persoon IF, Huse SM, Keijser BJ, Wesselink PR, Crielaard $W$ et al. Ecology of the microbiome of the infected root canal system: a comparison between apical and coronal root segments. Int Endod J. 2012 Jun;45(6):530-41. https://doi.org/10.1111/j.1365-2591.2011.02006.x

72. Sundqvist $G$. Bacteriological studies of necrotic pulps [Thesis]. Umeå, Swedem: University of Umeå; 1976.

73. Yoshida M, Fukushima H, Yamamoto K, Ogawa K, Toda T, Sagawa H. Correlation between clinical symptoms and microorganisms isolated from root canals of teeth with periapical pathosis. J Endod. 1987 Jan;13(1):24-8. https://doi.org/10.1016/S0099-2399(87)80088-2

74. Jacinto RC, Gomes BP, Ferraz CC, Zaia AA, Souza Filho FJ. Microbiological analysis of infected root canals from symptomatic and asymptomatic teeth with periapical periodontitis and the antimicrobial susceptibility of some isolated anaerobic bacteria. Oral Microbiol Immunol. 2003 Oct;18(5):285-92. https://doi.org/10.1034/i.1399-302X.2003.00078.x

75. Rôças IN, Siqueira Junior JF, Debelian GJ. Analysis of symptomatic and asymptomatic primary root canal infections in adult Norwegian patients. J Endod. 2011 Sep;37(9):120612. https://doi.org/10.1016/i.joen.2011.05.026

76. Rôças IN, Siqueira Junior JF. Frequency and levels of candidate endodontic pathogens in acute apical abscesses as compared to asymptomatic apical periodontitis. PLoS One. 2018 Jan;13(1):e0190469. https://doi.org/10.1371/journal.pone.0190469

77. Santos AL, Siqueira Junior JF, Rôças IN, Jesus EC, Rosado AS, Tiedje JM. Comparing the bacterial diversity of acute and chronic dental root canal infections. PLoS One. 2011;6(11):e28088. https://doi.org/10.1371/journal.pone.0028088 
78. Siqueira Junior JF, Rôças IN. Microbiology and treatment of acute apical abscesses. Clin Microbiol Rev. 2013 Apr;26(2):255-73. https://doi.org/10.1128/CMR.00082-12

79. Rôças IN, Siqueira Junior JF. Root canal microbiota of teeth with chronic apical periodontitis. J Clin Microbiol. 2008 Nov;46(11):3599-606. https://doi.org/10.1128/JCM.00431-08

80. Siqueira Junior JF, Rôças IN. Polymerase chain reactionbased analysis of microorganisms associated with failed endodontic treatment. Oral Surg Oral Med Oral Pathol Oral Radiol Endod. 2004 Jan;97(1):85-94. https://doi.org/10.1016/S1079-2104(03)00353-6

81. Ribeiro AC, Matarazzo F, Faveri M, Zezell DM, Mayer MP. Exploring bacterial diversity of endodontic microbiota by cloning and sequencing 16S rRNA. J Endod. 2011 Jul;37(7):922-6. https://doi.org/10.1016/i.joen.2011.04.007

82. Molander A, Reit C, Dahlén G, Kvist T.

Microbiological status of root-filled teeth with apical periodontitis. Int Endod J. 1998 Jan;31(1):1-7. https://doi.org/10.1046/j.1365-2591.1998.t01-1-00111.x

83. Sundqvist G, Figdor D, Persson S, Siögren U. Microbiologic analysis of teeth with failed endodontic treatment and the outcome of conservative re-treatment. Oral Surg Oral Med Oral Pathol Oral Radiol Endod. 1998 Jan;85(1):86-93. https://doi.org/10.1016/S1079-2104(98)90404-8

84. Siqueira Junior JF, Rôças IN, Lopes HP, Elias $\mathrm{CN}$, Uzeda M. Fungal infection of the radicular dentin. J Endod. 2002 Nov;28(11):770-3. https://doi.org/10.1097/00004770-200211000-00006

85. Pinheiro ET, Gomes BP, Ferraz CC, Sousa EL, Teixeira FB, Souza-Filho FJ. Microorganisms from canals of root-filled teeth with periapical lesions. Int Endod J. 2003 Jan;36(1):111. https://doi.org/10.1046/j.1365-2591.2003.00603.x

86. Anderson AC, Hellwig E, Vespermann R, Wittmer A, Schmid M, Karygianni $L$ et al. Comprehensive analysis of secondary dental root canal infections: a combination of culture and culture-independent approaches reveals new insights. PLoS One. 2012;7(11):e49576. https://doi.org/10.1371/journal.pone.0049576

87. Slots J, Sabeti M, Simon JH. Herpesviruses in periapical pathosis: an etiopathogenic relationship? Oral Surg Oral Med Oral Pathol Oral Radiol Endod. 2003 Sep;96(3):32731. https://doi.org/10.1016/S1079-2104(03)00352-4

88. Sabeti M, Simon JH, Slots J. Cytomegalovirus and EpsteinBarr virus are associated with symptomatic periapical pathosis. Oral Microbiol Immunol. 2003 Oct;18(5):327-8. https://doi.org/10.1034/i.1399-302X.2003.00079.x

89. Sabeti M, Kermani V, Sabeti S, Simon JH. Significance of human cytomegalovirus and Epstein-Barr virus in inducing cytokine expression in periapical lesions. J Endod. 2012 Jan;38(1):47-50. https://doi.org/10.1016/i.joen.2011.09.026

90. Ferreira DC, Paiva SS, Carmo FL, Rôças IN, Rosado AS, Santos KR et al. Identification of herpesviruses types 1 to 8 and human papillomavirus in acute apical abscesses. J Endod. 2011 Jan;37(1):10-6. https://doi.org/10.1016/j.joen.2010.09.009
91. Vianna ME, Conrads G, Gomes BP, Horz HP. Identification and quantification of archaea involved in primary endodontic infections. J Clin Microbiol. 2006 Apr;44(4):1274-82. https://doi.org/10.1128/JCM.44.4.1274-1282.2006

92. Munson MA, Pitt-Ford T, Chong B, Weightman A, Wade WG. Molecular and cultural analysis of the microflora associated with endodontic infections. J Dent Res. 2002 Nov;81(11):7616. https://doi.org/10.1177/0810761

93. Fisher K, Phillips $C$. The ecology, epidemiology and virulence of Enterococcus. Microbiology. 2009 Jun;155(P+ 6):1749-57. https://doi.org/10.1099/mic.0.026385-0

94. Love RM. Enterococcus faecalis: a mechanism for its role in endodontic failure. Int Endod J. 2001 Jul;34(5):399-405. https://doi.org/10.1046/j.1365-2591.2001.00437.x

95. Kayaoglu G, Erten H, Bodrumlu E, Ørstavik D. The resistance of collagen-associated, planktonic cells of Enterococcus faecalis to calcium hydroxide. J Endod. 2009 Jan;35(1):46-9. https://doi.org/10.1016/i.joen.2008.09.014

96. Gomes BP, Pinheiro ET. Extraradicular endodontic infections. In: Fouad AF, editor. Endodontic microbiology. 2nd ed. Hoboken: John Wiley \& Sons; 2017. p. 129-48. https://doi.org/10.1002/9781119080343.ch6

97. Sousa EL, Ferraz CC, Gomes BP, Pinheiro ET, Teixeira FB, Souza-Filho FJ. Bacteriological study of root canals associated with periapical abscesses. Oral Surg Oral Med Oral Pathol Oral Radiol Endod. 2003 Sep;96(3):332-9. https://doi.org/10.1016/S1079-2104(03)00261-0

98. Montagner F, Gomes BP, Kumar PS. Molecular fingerprinting reveals the presence of unique communities associated with paired samples of root canals and acute apical abscesses. J Endod. 2010 Sep;36(9):1475-9. https://doi.org/10.1016/i.joen.2010.06.004

99. Montagner F, Jacinto RC, Signoretti FG, Sanches PF, Gomes BP. Clustering behavior in microbial communities from acute endodontic infections. J Endod. 2012 Feb;38(2):158-62. https://doi.org/10.1016/i.joen.2011.09.029

100. Glickman GN, Bakland LK, Fouad AF, Hargreaves KM, Schwartz SA. Diagnostic terminology: report of an online survey. J Endod. 2009 Dec;35(12):1625-33. https://doi.org/10.1016/i.joen.2009.09.034

101. Alsulaimani RS. Single-visit endodontic treatment of mature teeth with chronic apical abscesses using mineral trioxide aggregate cement: a randomized clinical trial. BMC Oral Health. 2016 Aug;16(1):78. https://doi.org/10.1186/s12903-016-0276-y

102. Tennert C, Fuhrmann M, Wittmer A, Karygianni $L$, Altenburger MJ, Pelz K, et al. New bacterial composition in primary and persistent/secondary endodontic infections with respect to clinical and radiographic findings. J Endod. 2014 May;40(5):670-7. https://doi.org/10.1016/i.joen.2013.10.005

103. Costerton JW, Lewandowski Z, DeBeer D, Caldwell D, Korber D, James G. Biofilms, the customized microniche. J Bacteriol. 1994 Apr;176(8):2137-42. https://doi.org/10.1128/jb.176.8.2137-2142.1994 
104. Costerton JW, Stewart PS, Greenberg EP. Bacterial biofilms: a common cause of persistent infections. Science. 1999 May;284(5418):1318-22. https://doi.org/10.1126/science.284.5418.1318

105. Wimpenny J, Manz W, Szewzyk U. Heterogeneity in biofilms. FEMS Microbiol Rev. 2000 Dec;24(5):661-71. https://doi.org/10.1111/j.1574-6976.2000.tb00565.x

106. Ricucci D, Siqueira Junior JF. Biofilms and apical periodontitis: study of prevalence and association with clinical and histopathologic findings. J Endod. 2010 Aug;36(8):127788. https://doi.org/10.1016/j.joen.2010.04.007

107. Mohammadi Z, Palazzi F, Giardino L, Shalavi S. Microbial biofilms in endodontic infections: an update review. Biomed J. 2013 Mar-Apr;36(2):59-70. https://doi.org/10.4103/2319-4170.110400

108. Palmer RJ Jr, White DC. Developmental biology of biofilms: implications for treatment and control. Trends Microbiol. 1997 Nov;5(11):435-40. https://doi.org/10.1016/S0966-842X(97)01142-6

109. Ceri H, Olson ME, Stremick C, Read RR, Morck D, Buret A. The Calgary Biofilm Device: new technology for rapid determination of antibiotic susceptibilities of bacterial biofilms. J Clin Microbiol. 1999 Jun;37(6):1771-6.

110. Caroff M, Karibian D. Structure of bacterial lipopolysaccharides. Carbohydr Res. 2003 Nov;338(23):2431-47. https://doi.org/10.1016/j.carres.2003.07.010

111. Lipscomb IP, Sihota AK, Keevil CW. Comparative study of surgical instruments from sterile-service departments for presence of residual gram-negative endotoxin and proteinaceous deposits. J Clin Microbiol. 2006 Oct;44(10):3728-33. https://doi.org/10.1128/JCM.01280-06

112. Miyamoto T, Okano S, Kasai N. Inactivation of Escherichia coli endotoxin by soft hydrothermal processing. Appl Environ Microbiol. 2009 Aug;75(15):5058-63. https://doi.org/10.1128/AEM.00122-09

113. Gomes BP, Martinho FC, Vianna ME. Comparison of $2.5 \%$ sodium hypochlorite and $2 \%$ chlorhexidine gel on oral bacterial lipopolysaccharide reduction from primarily infected root canals. J Endod. 2009 Oct;35(10):1350-3. https://doi.org/10.1016/i.joen.2009.06.011

114. Safavi KE, Nichols FC. Effect of calcium hydroxide on bacterial lipopolysaccharide. J Endod. 1993 Feb;19(2):76-8. https://doi.org/10.1016/S0099-2399(06)81199-4

115. Beutler B. Endotoxin, toll-like receptor 4 , and the afferent limb of innate immunity. Curr Opin Microbiol. 2000 Feb;3(1):23-8. https://doi.org/10.1016/S1369-5274(99)00046-6

116. Dixon DR, Darveau RP. Lipopolysaccharide heterogeneity: innate host responses to bacterial modification of lipid a structure. J Dent Res. 2005 Jul;84(7):584-95. https://doi.org/10.1177/154405910508400702

117. Jain S, Darveau RP. Contribution of Porphyromonas gingivalis lipopolysaccharide to periodontitis. Periodontol 2000. 2010 Oct;54(1):53-70. https://doi.org/10.1111/j.1600-0757.2009.00333.x
118. Jain S, Coats SR, Chang AM, Darveau RP. A novel class of lipoprotein lipase-sensitive molecules mediates Toll-like receptor 2 activation by Porphyromonas gingivalis. Infect Immun. 2013 Apr;81(4):1277-86. https://doi.org/10.1128/IAI.01036-12

119. Elin RJ, Wolff SM. Biology of endotoxin. Annu Rev Med. 1976;27(1):127-41. https://doi.org/10.1146/annurev.me.27.020176.001015

120. To TT, Gümüş P, Nizam N, Buduneli N, Darveau RP. Subgingival plaque in periodontal health antagonizes at toll-like receptor 4 and inhibits e-selectin expression on endothelial cells. Infect Immun. 2015 Oct;84(1):120-6. https://doi.org/10.1128/IAl.00693-15

121. Wilson M, Reddi K, Henderson B. Cytokine-inducing components of periodontopathogenic bacteria. J Periodontal Res. 1996 Aug;31(6):393-407. https://doi.org/10.1111/j.1600-0765.1996.tb00508.x

122. Beutler B, Poltorak A. Positional cloning of Lps, and the general role of toll-like receptors in the innate immune response. Eur Cytokine Netw. 2000 Jun;11(2):143-52.

123. Bainbridge BW, Coats SR, Darveau RP. Porphyromonas gingivalis lipopolysaccharide displays functionally diverse interactions with the innate host defense system. Ann Periodontol. 2002 Dec;7(1):29-37. https://doi.org/10.1902/annals.2002.7.1.29

124. Haijar AM, Ernst RK, Tsai JH, Wilson CB, Miller SI. Human Toll-like receptor 4 recognizes host-specific LPS modifications. Nat Immunol. 2002 Apr;3(4):354-9. https://doi.org/10.1038/ni777

125. Al-Qutub MN, Braham PH, Karimi-Naser LM, Liu X, Genco CA, Darveau RP. Hemin-dependent modulation of the lipid A structure of Porphyromonas gingivalis lipopolysaccharide. Infect Immun. 2006 Aug;74(8):4474-85. https://doi.org/10.1128/IAI.01924-05

126. Martinho FC, Leite FR, Nóbrega LM, Endo MS, Nascimento GG, Darveau RP, et al. Comparison of Fusobacterium nucleatum and Porphyromonas gingivalis lipopolysaccharides clinically isolated from root canal infection in the induction of pro-inflammatory cytokines secretion. Braz Dent J. 2016b Mar-Apr;27(2):202-7. https://doi.org/10.1590/0103-6440201600572

127. Duerden BI. Virulence factors in anaerobes. Clin Infect Dis. 1994 May;18 Suppl 4:S253-9. https://doi.org/10.1093/clinids/18.Supplement_4.S253

128. Bennett KW, Eley A. Fusobacteria: new taxonomy and related diseases. J Med Microbiol. 1993 Oct;39(4):246-54. https://doi.org/10.1099/00222615-39-4-246

129. Holst O, Ulmer AJ, Brade H, Flad HD, Rietschel ET. Biochemistry and cell biology of bacterial endotoxins. FEMS Immunol Med Microbiol. 1996 Dec;16(2):83-104. https://doi.org/10.1111/j.1574-695X.1996.tb00126.x

130. Farber PA, Seltzer S. Endodontic microbiology. I. Etiology. J Endod. 1988 Jul;14(7):363-71. https://doi.org/10.1016/S0099-2399(88)80200-0 
131. Cardoso FG, Ferreira NS, Martinho FC, Nascimento GG, Manhães Junior LR, Rocco MA et al. Correlation between volume of apical periodontitis determined by cone-beam computed tomography analysis and endotoxin levels found in primary root canal infection. J Endod. 2015 Jul;41 (7):1015-9. https://doi.org/10.1016/i.joen.2015.02.005

132. Cardoso FG, Chung A, Martinho FC, Camargo CH, Carvalho CA, Gomes BP et al. Investigation of bacterial contents from persistent endodontic infection and evaluation of their inflammatory potential. Braz Dent J. 2016 Jul-Aug;27(4):412-8. https://doi.org/10.1590/0103-6440201600520

133. Vianna ME, Horz HP, Conrads G, Zaia AA, Souza-Filho FJ, Gomes BP. Effect of root canal procedures on endotoxins and endodontic pathogens. Oral Microbiol Immunol. 2007 Dec;22(6):411-8. https://doi.org/10.1111/j.1399-302X.2007.00379.x

134. Martinho FC, Chiesa WM, Marinho AC, Zaia AA, Ferraz CC, Almeida JF et al. Clinical investigation of the efficacy of chemomechanical preparation with rotary nickeltitanium files for removal of endotoxin from primarily infected root canals. J Endod. 2010b Nov;36(11):1766-9. https://doi.org/10.1016/i.joen.2010.08.019

135. Oliveira LD, Carvalho CA, Carvalho AS, Alves JS, Valera MC, Jorge $A O$. Efficacy of endodontic treatment for endotoxin reduction in primarily infected root canals and evaluation of cytotoxic effects. J Endod. 2012 Aug;38(8):1053-7. https://doi.org/10.1016/i.joen.2012.04.015

136. Xavier AC, Martinho FC, Chung A, Oliveira LD, Jorge $A O$, Valera $M C$ et al. One-visit versus two-visit root canal treatment: effectiveness in the removal of endotoxins and cultivable bacteria. J Endod. 2013 Aug;39(8):959-64. https://doi.org/10.1016/i.joen.2013.04.027

137. Marinho AC, Martinho FC, Zaia AA, Ferraz CC, Gomes BP. Monitoring the effectiveness of root canal procedures on endotoxin levels found in teeth with chronic apical periodontitis. J Appl Oral Sci. 2014 Nov-Dec;22(6):490-5. https://doi.org/10.1590/1678-775720130664

138. Sousa EL, Martinho FC, Nascimento GG, Leite FR, Gomes BP. Quantification of endotoxins in infected root canals and acute apical abscess exudates: monitoring the effectiveness of root canal procedures in the reduction of endotoxins. J Endod. 2014b Feb;40(2):177-81. https://doi.org/10.1016/i.joen.2013.10.008

139. Herrera DR, Martinho FC, de-Jesus-Soares A, Zaia AA, Ferraz CC, Almeida JF et al. Clinical efficacy of EDTA ultrasonic activation in the reduction of endotoxins and cultivable bacteria. Int Endod J. 2017 Oct;50(10):933-40. https://doi.org/10.1111/iej.12713

140. Duque TM, Prado M, Herrera DR, Gomes BP. Periodontal and endodontic infectious/inflammatory profile in primary periodontal lesions with secondary endodontic involvement after a calcium hydroxide-based intracanal medication. Clin Oral Investig. 2018 Mar. https://doi.org/10.1007/s00784-018-2401-6

141. Martinho FC, Chiesa WM, Zaia AA, Ferraz CC, Almeida JF, Souza-Filho FJ et al. Comparison of endotoxin levels in previous studies on primary endodontic infections. J Endod. $2011 \mathrm{~b}$ Feb;37(2):163-7. https://doi.org/10.1016/i.joen.2010.11.020
142. Hong CY, Lin SK, Kok SH, Cheng SJ, Lee MS, Wang TM et al. The role of lipopolysaccharide in infectious bone resorption of periapical lesion. J Oral Pathol Med. 2004 Mar;33(3):162-9. https://doi.org/10.1111/i.0904-2512.2004.00045.x

143. Brito LC, Teles FR, Teles RP, Totola AH, Vieira LQ, Ribeiro Sobrinho AP. T-lymphocyte and cytokine expression in human inflammatory periapical lesions. J Endod. 2012 Apr;38(4):481-5. https://doi.org/10.1016/i.joen.2011.12.010

144. Parolia A, Gee LS, Porto ICM, Mohan M. Role of cytokines, endotoxins (LPS), and lipoteichoic acid (LTA) in endodontic infection. J Dent Oral Disord Ther. 2014;2(4):1-5. https://doi.org/10.15226/jdodt.2014.00132

145. Martin TJ, Romas E, Gillespie MT. Interleukins in the control of osteoclast differentiation. Crit Rev Eukaryot Gene Expr. 1998;8(2):107-23. https://doi.org/10.1615/CritRevEukarGeneExpr.v8.i2.10

146. Fukushima A, Kajiya H, Izumi T, Shigeyama C, Okabe $\mathrm{K}$, Anan $\mathrm{H}$. Pro-inflammatory cytokines induce suppressor of cytokine signaling- 3 in human periodontal ligament cells. J Endod. 2010 Jun;36(6):1004-8. https://doi.org/10.1016/i.joen.2010.02.027

147. Bambirra W Jr, Maciel KF, Thebit MM, Brito LC, Vieira LQ, Ribeiro Sobrinho AP. Assessment of apical expression of alpha-2 integrin, heat shock protein, and proinflammatory and immunoregulatory cytokines in response to endodontic infection. J Endod. 2015 Jul;41(7):1085-90. https://doi.org/10.1016/i.joen.2015.03.002

148. Yamaguchi H, Ozeki N, Kawai R, Tanaka T, Hiyama T, Nakata K et al. Proinflammatory cytokines induce stromelysin-1-mediated cell proliferation in dental pulp fibroblast-like cells. J Endod. 2014 Jan;40(1):89-94. https://doi.org/10.1016/i.joen.2013.09.029

149. Draing C, Sigel S, Deininger S, Traub S, Munke R, Mayer $\mathrm{C}$ et al. Cytokine induction by Gram-positive bacteria. Immunobiology. 2008;213(3-4):285-96. https://doi.org/10.1016/j.imbio.2007.12.001

150. Deininger S, Traub S, Aichele D, Rupp T, Baris T, Möller $\mathrm{HM}$ et al. Presentation of lipoteichoic acid potentiates its inflammatory activity. Immunobiology. 2008;213(6):519-29. https://doi.org/10.1016/i.imbio.2008.01.001

151. Lee JK, Baik JE, Yun CH, Lee K, Han SH, Lee W et al. Chlorhexidine gluconate attenuates the ability of lipoteichoic acid from Enterococcus faecalis to stimulate toll-like receptor 2. J Endod. 2009 Feb;35(2):212-5. https://doi.org/10.1016/i.joen.2008.10.018

152. Baik JE, Ryu YH, Han JY, Im J, Kum KY, Yun CH et al. Lipoteichoic acid partially contributes to the inflammatory responses to Enterococcus faecalis. J Endod. 2008 Aug;34(8):975-82. https://doi.org/10.1016/i.joen.2008.05.005

153. Baik JE, Choe HI, Hong SW, Kang SS, Ahn KB, Cho K et al. Human salivary proteins with affinity to lipoteichoic acid of Enterococcus faecalis. Mol Immunol. 2016 Sep;77:52-9. https://doi.org/10.1016/j.molimm.2016.07.013 
154. Birkedal-Hansen H. Role of cytokines and inflammatory mediators in tissue destruction. J Periodontal Res. 1993 Nov;28(6 Pt 2):500-10. https://doi.org/10.1111/i.1600-0765.1993.tb02113.x

155. Abbas A, Lichtman A, Pillai S. Basic immunology functions and disorders of the immune system. 4th ed. Philadelphia: Saunders/ Elsevier; 2012.

156. Champagne CM, Buchanan W, Reddy MS, Preisser JS, Beck JD, Offenbacher S. Potential for gingival crevice fluid measures as predictors of risk for periodontal diseases. Periodontol 2000. 2003;31(1):167-80. https://doi.org/10.1034/j.1600-0757.2003.03110.x

157. Gonçalves PF, Huang H, McAninley S, Alfant B, Harrison $\mathrm{P}$, Aukhil I et al. Periodontal treatment reduces matrix metalloproteinase levels in localized aggressive periodontitis. J Periodontol. 2013 Dec;84(12):1801-8. https://doi.org/10.1902/jop.2013.130002

158. Delaleu N, Bickel M. Interleukin - $1 \beta$ and Interleukin-18: regulation and activity in local inflammation. Periodontol 2000. 2004;35:4252. https://doi.org/10.1111/i.0906-6713.2004.003569.x

159. Fujisaki K, Tanabe N, Suzuki N, Kawato T, Takeichi $O$, Tsuzukibashi $O$ et al. Receptor activator of NF-kappaB ligand induces the expression of carbonic anhydrase II, cathepsin K, and matrix metalloproteinase-9 in osteoclast precursor RAW264.7 cells. Life Sci. 2007 Mar;80(14):13118. https://doi.org/10.1016/j.lfs.2006.12.037

160. Garrido M, Dezerega A, Bordagaray MJ, Reyes M, Vernal $R$, Melgar-Rodríguez $S$ et al. C-reactive protein expression is up-regulated in apical lesions of endodontic origin in association with interleukin-6. J Endod. 2015 Apr;41(4):4649. https://doi.org/10.1016/i.joen.2014.12.021

161. Moore KW, O'Garra A, de Waal Malefyt R, Vieira P, Mosmann TR. Interleukin-10. Annu Rev Immunol. 1993;11(1):165-90. https://doi.org/10.1146/annurev.iy.11.040193.001121

162. Mosmann TR, Sad S. The expanding universe of T-cell subsets: Th1, Th2 and more. Immunol Today. 1996 Mar;17(3):138-46. https://doi.org/10.1016/0167-5699(96)80606-2

163. De Waal RM, Haanen J, Spits H, Roncarolo MG, Te Velde A, Figdor $C$ et al. Interleukin 10 (IL-10) and viral IL-10 strongly reduce antigen-specific human $\mathrm{T}$ cell proliferation by diminishing the antigen-presenting capacity of monocytes via downregulation of class II major histocompatibility complex expression. J Exp Med. 1991;174(5):1209-20.

164. Fiorentino DF, Zlotnik A, Mosmann TR, Howard M, O'Garra, A. IL-10 inhibits cytokine production by activated macrophages. J Immunol. 1991;147(11):3815-22.

165. Willems F, Marchant A, Delville JP, Gérard C, Delvaux A, Velu Tet al. Interleukin-10 inhibits B7 and intercellular adhesion molecule-1 expression on human monocytes. Eur J Immunol. 1994 Apr;24(4):1007-9. https://doi.org/10.1002/eji.1830240435

166. Itoh T, Nakamura H, Kishi J, Hayakawa T. The activation of matrix metalloproteinases by a whole-cell extract from Prevotella nigrescens. J Endod. 2009 Jan;35(1):55-9. https://doi.org/10.1016/j.joen.2008.09.012
167. Ahmed GM, El-Baz AA, Hashem AA, Shalaan AK. Expression levels of matrix metalloproteinase-9 and gram-negative bacteria in symptomatic and asymptomatic periapical lesions. J Endod. 2013 Apr;39(4):444-8. https://doi.org/10.1016/i.joen.2012.11.009

168. Paula-Silva FW, Silva LA, Kapila YL. Matrix metalloproteinase expression in teeth with apical periodontitis is differentially modulated by the modality of root canal treatment. J Endod. 2010 Feb;36(2):231-7. https://doi.org/10.1016/i.joen.2009.10.030

169. Verma RP, Hansch C. Matrix metalloproteinases (MMPs): chemical-biological functions and $(Q)$ SARs. Bioorg Med Chem. 2007 Mar;15(6):2223-68. https://doi.org/10.1016/j.bmc.2007.01.011

170. Shin SJ, Lee JI, Baek SH, Lim SS. Tissue levels of matrix metalloproteinases in pulps and periapical lesions. J Endod. 2002 Apr;28(4):313-5. https://doi.org/10.1097/00004770-200204000-00013

171. Tsai CH, Chen YJ, Huang FM, Su YF, Chang YC. The upregulation of matrix metalloproteinase-9 in inflamed human dental pulps. J Endod. 2005 Dec;31(12):860-2. https://doi.org/10.1097/01.don.0000164851.55389.4e

172. Collier IE, Legant W, Marmer B, Lubman O, Saffarian $S$, Wakatsuki T et al. Diffusion of MMPs on the surface of collagen fibrils: the mobile cell surface-collagen substratum interface. PLoS One. 2011;6(9):e24029. https://doi.org/10.1371/journal.pone.0024029

173. Chow AK, Cena J, Schulz R. Acute actions and novel targets of matrix metalloproteinases in the heart and vasculature. Br J Pharmacol. 2007 Sep;152(2):189-205. https://doi.org/10.1038/si.bjp.0707344

174. Tsuji M, Yamasaki M, Amano K, Matsui H, Morimoto $T$, Nakamura $H$. Histochemical localization of neutral proteases released during development of rat periradicular lesion. Arch Oral Biol. 2009 Dec;54(12):1128-35. https://doi.org/10.1016/i.archoralbio.2009.10.003

175. Murate T, Hayakawa T. Multiple functions of tissue inhibitors of metalloproteinases (TIMPs): new aspects in hematopoiesis. Platelets. 1999;10(1):5-16. https://doi.org/10.1080/09537109976293

176. Nagase H, Woessner JF Jr. Matrix metalloproteinases. J Biol Chem. 1999 Jul;274(31):21491-4. https://doi.org/10.1074/ibc.274.31.21491

177. Brosnahan AJ, Schlievert PM. Gram-positive bacterial superantigen outside-in signaling causes toxic shock syndrome. FEBS J. 2011 Dec;278(23):4649-67. https://doi.org/10.1111/j.1742-4658.2011.08151.x

178. Griffee MB, Patterson SS, Miller CH, Kafrawy AH, Newton $\mathrm{CW}$. The relationship of Bacteroides melaninogenicus to symptoms associated with pulpal necrosis. Oral Surg Oral Med Oral Pathol. 1980 Nov;50(5):457-61. https://doi.org/10.1016/S0030-4220(80)80015-6 
179. Haapasalo M. Bacteroides spp. in dental root canal infections. Endod Dent Traumatol. 1989 Feb;5(1):1-10. https://doi.org/10.1111/j.1600-9657.1989.tb00330.x

180. Sundqvist G, Johansson E, Siögren U. Prevalence of black-pigmented bacteroides species in root canal infections. J Endod. 1989 Jan;15(1):13-9. https://doi.org/10.1016/S0099-2399(89)80092-5

181. Hashioka K, Yamasaki M, Nakane A, Horiba N, Nakamura $\mathrm{H}$. The relationship between clinical symptoms and anaerobic bacteria from infected root canals. J Endod. 1992 Nov;18(11):558-61. https://doi.org/10.1016/S0099-2399(06)81214-8

182. Vineet RV, Nayak M, Kotigaddle S. Association of endodontic signs and symptoms with root canal pathogens: a clinical comparative study. Saudi Endod J. 2016;6(2):82-6. https://doi.org/10.4103/1658-5984.180621

183. Dahlén G, Bergenholtz G. Endotoxic activity in teeth with necrotic pulps. J Dent Res. 1980 Jun;59(6):1033-40. https://doi.org/10.1177/00220345800590060501

184. Silva N, Dutzan N, Hernandez M, Dezerega A, Rivera $\mathrm{O}$, Aguillon JC et al. Characterization of progressive periodontal lesions in chronic periodontitis patients: levels of chemokines, cytokines, matrix metalloproteinase-13, periodontal pathogens and inflammatory cells. J Clin Periodontol. 2008 Mar;35(3):206-14. https://doi.org/10.1111/j.1600-051X.2007.01190.x

185. Page-McCaw A, Ewald AJ, Werb Z. Matrix metalloproteinases and the regulation of tissue remodelling. Nat Rev Mol Cell Biol. 2007 Mar;8(3):221-33. https://doi.org/10.1038/nrm2125

186. Gill SE, Parks WC. Metalloproteinases and their inhibitors: regulators of wound healing. Int J Biochem Cell Biol. 2008;40(6-7):1334-47. https://doi.org/10.1016/j.biocel.2007.10.024

187. Rydlova M, Holubec L Jr, Ludvikova M Jr, Kalfert D, Franekova J, Povysil $C$ et al. Biological activity and clinical implications of the matrix metalloproteinases. Anticancer Res. 2008 Mar-Apr;28 2B:1389-97.

188. Siqueira Junior JF, Alves FR, Versiani MA, Rôças IN, Almeida $B M$, Neves MA et al. Correlative bacteriologic and microcomputed tomographic analysis of mandibular molar mesial canals prepared by self-adjusting file, reciproc, and twisted file systems. J Endod. 2013 Aug;39(8):1044-50. https://doi.org/10.1016/i.joen.2013.04.034

189. Peters OA, Arias A, Paqué F. A Micro-computed Tomographic Assessment of Root Canal Preparation with a Novel Instrument, TRUShape, in Mesial Roots of Mandibular Molars. J Endod. 2015 Sep;41(9):1545-50. https://doi.org/10.1016/i.joen.2015.06.007

190. Zuolo ML, Zaia AA, Belladonna FG, Silva EJ, Souza EM, Versiani MA, et al. Micro-CT assessment of the shaping ability of four root canal instrumentation systems in ovalshaped canals. Int Endod J. 2018 May;51*5):564-71. https://doi.org/10.1111/iej.12810
191. Gomes BP, Vianna ME, Zaia AA, Almeida JF, Souza-Filho FJ, Ferraz CC. Chlorhexidine in endodontics. Braz Dent J. 2013;24(2):89-102. https://doi.org/10.1590/0103-6440201302188

192. Zehnder M. Root canal irrigants. J Endod. 2006 May;32(5):389-98. https://doi.org/10.1016/i.joen.2005.09.014

193. Khademi AA, Mohammadi Z, Havaee A. Evaluation of the antibacterial substantivity of several intracanal agents. Aust Endod J. 2006 Dec;32(3):112-5. https://doi.org/10.1111/i.1747-4477.2006.00033.x

194. Herrera DR, Durand-Ramirez JE, Falcão A, Silva EJ, Santos EB, Gomes BP. Antimicrobial activity and substantivity of Uncaria tomentosa in infected root canal dentin. Braz Oral Res. 2016;30(1):e61. https://doi.org/10.1590/1807-3107BOR-2016.vol30.0061

195. Trevino EG, Patwardhan AN, Henry MA, Perry G, Dybdal-Hargreaves N, Hargreaves KM et al. Effect of irrigants on the survival of human stem cells of the apical papilla in a platelet-rich plasma scaffold in human root tips. J Endod. 2011 Aug;37(8):1109-15. https://doi.org/10.1016/i.joen.2011.05.013

196. Schmidt TF, Teixeira CS, Felippe MC, Felippe WT, Pashley $\mathrm{DH}$, Bortoluzzi EA. Effect of ultrasonic activation of irrigants on smear layer removal. J Endod. 2015 Aug;41(8):1359-63. https://doi.org/10.1016/i.joen.2015.03.023

197. Gu LS, Kim JR, Ling J, Choi KK, Pashley DH, Tay FR. Review of contemporary irrigant agitation techniques and devices. J Endod. 2009 Jun;35(6):791-804. https://doi.org/10.1016/i.joen.2009.03.010

198. Plotino G, Cortese T, Grande NM, Leonardi DP, Di Giorgio $G$, Testarelli $L$ et al. New technologies to improve root canal disinfection. Braz Dent J. 2016 Jan-Feb;27(1):3-8. https://doi.org/10.1590/0103-6440201600726

199. Caron G, Nham K, Bronnec F, Machtou P. Effectiveness of different final irrigant activation protocols on smear layer removal in curved canals. J Endod. 2010 Aug;36(8):1361-6. https://doi.org/10.1016/i.joen.2010.03.037

200. Herrera DR, Santos ZT, Tay LY, Silva EJ, Loguercio AD, Gomes BP. Efficacy of different final irrigant activation protocols on smear layer removal by EDTA and citric acid. Microsc Res Tech. 2013 Apr;76(4):364-9. https://doi.org/10.1002/jemt.22175

201. Jiang LM, Lak B, Eijsvogels LM, Wesselink P, Sluis LW. Comparison of the cleaning efficacy of different final irrigation techniques. J Endod. 2012 Jun;38(6):838-41. https://doi.org/10.1016/i.joen.2012.03.002

202. De Moor RJ, Blanken J, Meire M, Verdaasdonk R. Laser induced explosive vapor and cavitation resulting in effective irrigation of the root canal. Part 2: evaluation of the efficacy. Lasers Surg Med. 2009 Sep;41(7):520-3. https://doi.org/10.1002/lsm.20797

203. Schoeffel GJ. The EndoVac method of endodontic irrigation: safety first. Dent Today. 2007 Oct;26(10):92-6. 
204. Hems RS, Gulabivala K, Ng YL, Ready D, Spratt DA. An in vitro evaluation of the ability of ozone to kill a strain of Enterococcus faecalis. Int Endod J. 2005 Jan;38(1):22-9. https://doi.org/10.1111/j.1365-2591.2004.00891.x

205. Bergmans L, Moisiadis P, Teughels W, Van Meerbeek B, Quirynen M, Lambrechts P. Bactericidal effect of Nd:YAG laser irradiation on some endodontic pathogens ex vivo. Int Endod J. 2006 Jul;39(7):547-57. https://doi.org/10.1111/j.1365-2591.2006.01115.x

206. George S, Kishen A. Photophysical, photochemical, and photobiological characterization of methylene blue formulations for light-activated root canal disinfection. J Biomed Opt. 2007 May-Jun;12(3):034029. https://doi.org/10.1117/1.2745982

207. Noiri Y, Katsumoto T, Azakami H, Ebisu S. Effects of Er:YAG laser irradiation on biofilm-forming bacteria associated with endodontic pathogens in vitro. J Endod. 2008 Jul;34(7):8269. https://doi.org/10.1016/i.joen.2008.04.010

208.van der Sluis LW, Versluis M, Wu MK, Wesselink PR. Passive ultrasonic irrigation of the root canal: a review of the literature. Int Endod J. 2007 Jun;40(6):415-26. https://doi.org/10.1111/j.1365-2591.2007.01243.x

209. Nakamura VC, Pinheiro ET, Prado LC, Silveira AC, Carvalho AP, Mayer MP et al. Effect of ultrasonic activation on the reduction of bacteria and endotoxins in root canals: a randomized clinical trial. Int Endod J. 2018 Jan;51 Suppl 1:e12-22. https://doi.org/10.1111/iej.12783

210. Warren HS, Knights CV, Siber GR. Neutralization and lipoprotein binding of lipopolysaccharides in tolerant rabbit serum. J Infect Dis. 1986 Nov; 154(5):784-91. https://doi.org/10.1093/infdis/154.5.784

211. Cavaillon JM, Fitting C, Haeffner-Cavaillon N, Kirsch SJ, Warren HS. Cytokine response by monocytes and macrophages to free and lipoprotein-bound lipopolysaccharide. Infect Immun. 1990 Jul;58(7):2375-82.

212. Manfredi M, Figini L, Gagliani M, Lodi G. Single versus multiple visits for endodontic treatment of permanent teeth. Cochrane Database Syst Rev. 2016 Dec;12:CD005296. https://doi.org/10.1002/14651858.CD005296.pub3

213. Mohammadi Z, Dummer PM. Properties and applications of calcium hydroxide in endodontics and dental traumatology. Int Endod J. 2011 Aug;44(8):697-730. https://doi.org/10.1111/j.1365-2591.2011.01886.x

214. Silva L, Nelson-Filho P, Leonardo MR, Rossi MA, Pansani CA. Effect of calcium hydroxide on bacterial endotoxin in vivo. J Endod. 2002 Feb;28(2):94-8. https://doi.org/10.1097/00004770-200202000-00011 